CURSO DE ESPECIALIZAÇÃO EM DESENVOLVIMENTO HUMANO, EDUCAÇÃO E INCLUSÃO ESCOLAR - UAB/UnB

ATIVIDADE ASSISTIDA POR ANIMAIS - UMA PROPOSTA DE INCLUSÃO EDUCACIONAL COM A UTILIZAÇÃO DE ANIMAIS DE ESTIMAÇÃO.

ORIENTADORA: CARLA FRANCINI H. T. F. NASCIMENTO 


\title{
ATIVIDADE ASSISTIDA POR ANIMAIS - UMA PROPOSTA DE INCLUSÃO EDUCACIONAL COM A UTILIZAÇÃO DE ANIMAIS DE ESTIMAÇÃO.
}

\author{
Monografia apresentada ao Curso de Especialização \\ em Desenvolvimento Humano, Educação e Inclusão, da \\ Faculdade UAB/UNB - Pólo de Ceilândia Orientadora: Carla \\ Francini H. T. F. Nascimento.
}




\title{
TERMO DE APROVAÇÃO
}

CÁSSIA MARIA BORBA LINS DA SILVA

\section{ATIVIDADE ASSISTIDA POR ANIMAIS- UMA PROPOSTA DE INCLUSÃO EDUCACIONAL COM A UTILIZAÇÃO DE ANIMAIS DE ESTIMAÇÃO.}

\begin{abstract}
Monografia aprovada como requisito parcial para obtenção do grau de Especialista do Curso de Especialização em Desenvolvimento Humano, Educação e Inclusão Escolar - UAB/UnB. Apresentação ocorrida em $16 / 04 / 2011$.

Aprovada pela banca formada pelos professores:
\end{abstract}

CARLA FRANCINI H. T. F. NASCIMENTO

(Orientador)

MÍRIAN BARBOSA TAVARES RAPOSO

(Examinador)

CÁSSIA MARIA BORBA LINS DA SILVA

(Cursista)

BRASÍLIA/2011 


\section{DEDICATÓRIA:}

Dedico este trabalho aos meus alunos, com os quais aprendo constantemente, e aos meus queridos e fiéis "Amigos Especiais". 


\section{AGRADECIMENTOS}

Agradeço a Deus pela saúde e força para nunca desistir. À minha mãe, cujo amor e exemplo me fizeram crescer e desejar ser uma pessoa melhor. À Secretaria de Estado de Educação e à Universidade de Brasília, pela oportunidade. À minha orientadora, Carla Francini. Ao Centro de Ensino Especial, local em que trabalho e onde o estudo foi realizado. À equipe gestora, professores pais e alunos que contribuíram com a pesquisa. $E$ a todos aqueles que, direta ou indiretamente, ajudaram a realizar este trabalho. 


\section{SUMÁRIO}

RESUMO

.8

APRESENTAÇÃO

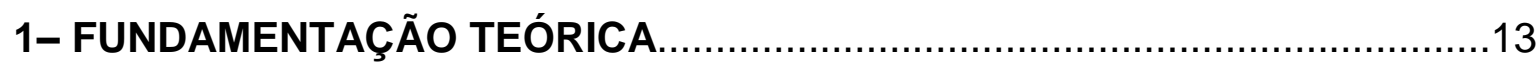

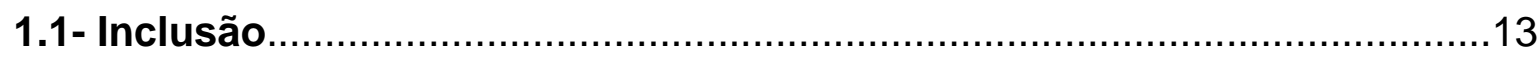

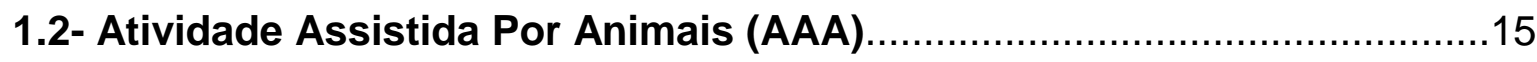

- 1.2.1-- A Prática Pedagógica e a Utilização de Animais Domésticos....20

- 1.2.2- A Utilização de Animais domésticos no Processo de Ensino

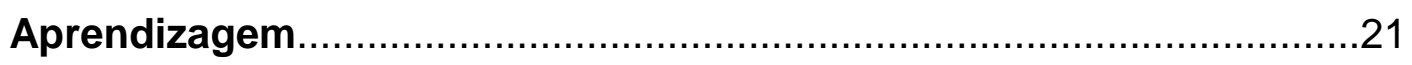

- 1.2.3- Conhecendo a Oficina Bichoterapia- Amigo Especial.................22

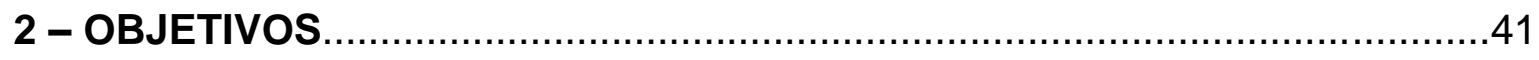

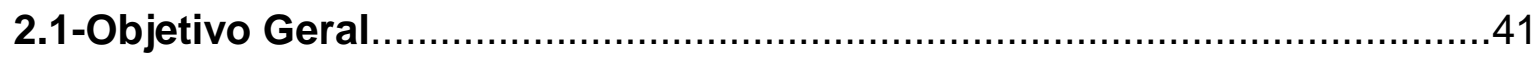

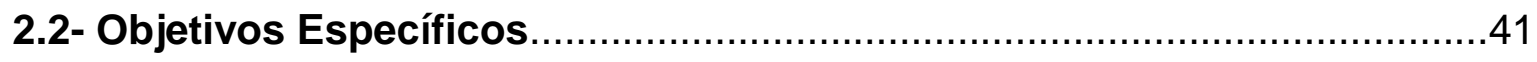

3 - METODOLOGIA

3.1- Fundamentação Teórica da Metodologia .............................................42

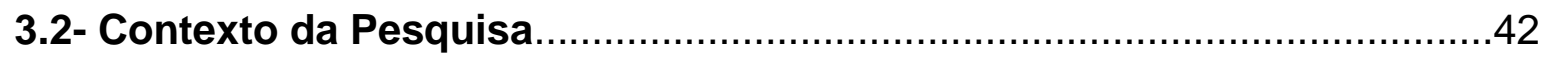

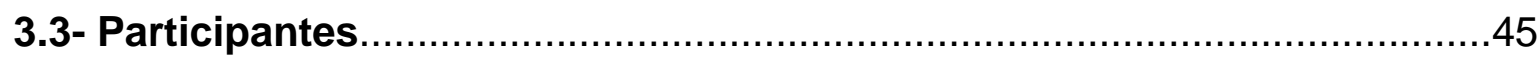

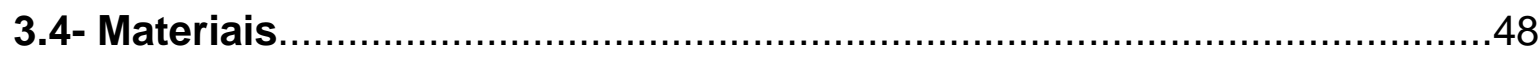

3.5- Instrumentos de Construção de Dados .................................................4

3.6- Procedimentos de Construção de Dados ..............................................48

3.7- Procedimentos de Análise de Dados....................................................49 


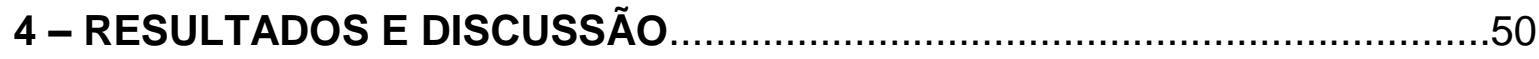

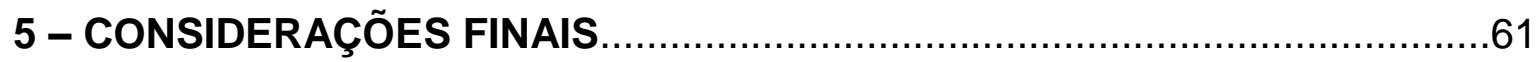

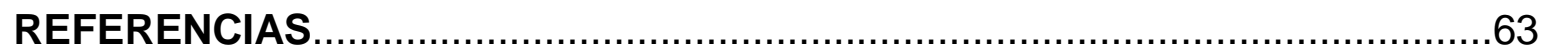

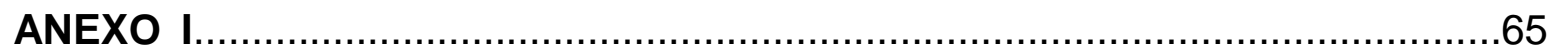




\section{RESUMO}

O presente trabalho teve por objetivo analisar as contribuições da Oficina Bichoterapia - Amigo Especial, na inclusão de alunos com Necessidades Educacionais Especiais. A Oficina desenvolvida pela autora está sendo realizada em um Centro de Ensino Especial do Distrito Federal. Este trabalho originou-se de um Projeto desenvolvido pela autora, O Bichoterapia. Há treze anos se dedicando ao Ensino Especial, na Secretaria de Estado de Educação do Distrito Federal (SEDF), a autora constatou que a interação de seus alunos com animais domésticos tinha como resultados ganhos significativos nas áreas pedagógica, social, física e emocional desses alunos. A partir de tal constatação, buscou-se um aprofundamento do conhecimento teórico existente sobre o tema Inclusão de Alunos com Necessidades Educacionais Especiais. O trabalho encontrou nas diversas áreas do conhecimento: pedagogia, psicologia, psiquiatria, veterinária, medicina; um importante suporte teórico para dar um maior embasamento à proposta aqui apresentada. Para atingir os objetivos propostos foram realizadas observações e entrevistas no local onde ocorre a Bichoterapia, com alunos, professores e membros da equipe de direção e de responsáveis legais dos alunos. Os resultados evidenciaram o reconhecimento dos participantes quanto às contribuições oferecidas, no âmbito da inclusão, pela Oficina Bichoterapia - Amigo Especial. A partir da análise dos resultados obtidos, concluiu-se que a Oficina Bichoterapia - Amigo Especial vem conseguindo atingir seus objetivos: contribuir com uma prática educacional voltada para a inclusão dos alunos com Necessidades Educacionais Especiais.

Palavra Chave: Bichoterapia. Contribuição. Inclusão. Alunos com Necessidades Educacionais Especiais. 


\section{APRESENTAÇÃO}

O primeiro contato da autora com a Educação Especial teve inicio há treze anos, quando a mesma viajou em férias à Brasília. Nunca havia imaginado que, a partir dessa viagem, a sua vida iria mudar de modo tão significativo.

$\mathrm{Na}$ época, por coincidência, estava sendo realizado um concurso para professores da Secretaria de Estado de Educação do Distrito Federal. Como já era da área, a autora prestou concurso e foi aprovada, sendo, alguns meses depois, convocada. Ao tomar posse, foi Ihe oferecida uma vaga no Ensino Especial. Apesar de ter cursado magistério, havia tempo que não exercia a profissão. Por essa razão, achava-se um pouco desatualizada na área educacional. No entanto, não teve receio em aceitar, pelo motivo de nunca temer desafios.

Iniciou seus trabalhos na Estimulação Precoce do Núcleo Bandeirante. A partir daí, se apaixonou pela Educação Especial. Desde então, realizou vários cursos na área e trabalhou em quase todas as especificidades da Educação Especial: Estimulação Precoce, Transtorno Global do Desenvolvimento (TGD) Deficiência Intelectual (DI), entre outras.

Em 2004, um pouco mais experiente, quando se encontrava trabalhando em um Centro de Ensino Especial do Guará, e apesar de reconhecer o ótimo trabalho dos muitos professores que trabalham nessa área, começou a sentir falta de uma prática pedagógica que estivesse mais de acordo com a realidade e a necessidade dos alunos com Necessidades Educacionais Especiais. Uma didática diferente, sem currículos prontos, tradicional, que transmitisse conteúdos que tivessem sentido e utilidade para esses mesmos alunos e cujas atividades fossem realizadas com prazer e não, como muitas vezes ocorria, apenas copiadas e por obrigação.

Durante essa mesma época, começou a cursar, pela Secretaria de Estado de Educação do Distrito Federal (SEDF), em Parceria com a Universidade de 
Brasília (UNB), um Curso de Graduação: PIE - Curso de Pedagogia para Professores em Exercício, em Início de Escolarização. Esse curso aguçou ainda mais o seu senso critico, o seu lado criativo e a sua "sede" pela pesquisa. Depois de tantos questionamentos e buscas, foi encontrar na experiência de vida uma alternativa para sua prática profissional.

Por pertencer a uma família numerosa, total de doze irmãos, foi muito difícil para a autora morar sozinha em Brasília. Descobrindo no animal doméstico um forte aliado nos momentos de solidão e tristeza, e acima de tudo, um amigo para todas as horas.

Surgiu o questionamento: se o animal foi, em momentos tão difíceis, importante para a autora, porque não o seria para outras pessoas? Não bastasse esse fato, 0 animal abstém-se de qualquer tipo de preconceito, sendo, na maioria das vezes, uma inesgotável fonte de carinho e companheirismo. A autora iniciou, então, a pesquisa sobre a "Pet Terapia" (Atividade por Meio dos Animais).

Estudos comprovaram o que já se sabia empiricamente: que o contato com os animais domésticos faz bem a muitas pessoas, inclusive como um atenuante da solidão: "Que os animais não apenas fazem as pessoas se sentir bem, como as fazem bem de fato" (Becker, 2003, p.32). A partir dessa constatação, chegou-se à seguinte conclusão: o animal seria o "instrumento" principal do projeto.

Diante dessas reflexões iniciou-se o estudo de um projeto que viesse a estimular os benefícios trazidos pela interação Homem e Animal. e consequentemente, por meio disso, desenvolver e enriquecer as áreas pedagógica, social, afetiva, física, as atividades da vida diária, promover a autoestima, a capacitação profissional, enfim, melhorar a qualidade de vida e trazer mais prazer e alegria à vida de todos os envolvidos.

Foi então que surgiu a idéia de promover Atividades Assistidas por Animais *(AAA) em uma escola de Educação Especial, dentro da grade horária dos alunos. Além de ser um método inovador de trabalhar as necessidades individuas de cada 
um, a AAA consegue, em certas situações, obter uma maior entrega dos participantes nas atividades propostas e Atividade Assistida por Animais usa-se um método bem diferente dos tradicionais: os "Matérias didáticos" são feitos de olhos irresistíveis, rabinhos abanando, e narizinhos charmosos; os conteúdos nele contidos são de grande valor: carinho, companheirismo, alegria, amizade e amor incondicional.

\section{Atividades Assistidas por Animais $\left(\mathrm{AAA}^{1}\right)$ :}

Segundo o que a Delta Society ${ }^{1}$ informa em seu site, a Atividade Assistida por Animais envolve serviços profissionais de diversas áreas (pedagógica, física, social, emocional, etc.), que utilizam o animal como parte do trabalho e do tratamento. A AAA é dirigida e desenvolvida para promover a saúde física, emocional e/ou funções cognitivas dos seus usuários. É um processo formal com procedimentos e metodologia documentado, planejado, tabulado, medido e seus resultados avaliados. Todos os progressos são verificados e reavaliados com o objetivo de atingir os objetivos do programa. Pode ser desenvolvido em grupo ou de forma individual. Ex.: visitas e atendimentos. Por vezes ocorrem algumas atividades lúdicas. São atividades desenvolvidas por profissionais treinados que levam seus animais às instituições. Essas atividades propõem o entretenimento, oportunidades de motivação e informação, a fim de melhorar a qualidade de vida. Ex: datas comemorativas, festas, promoção de eventos pedagógicos ou recreativos, etc.

O Projeto Bichoterapia - assim era intitulado - teve início em 2004, em um Centro de Ensino Especial localizado no Guará. Na época foi premiado com o primeiro lugar, pela Secretaria de Estado de Educação do Distrito Federal com o "Prêmio ao Professor", em outubro de 2004. Após um ano de sua inauguração, tomou posse uma nova direção no Centro Especial e uma nova proposta pedagógica foi apresentada. Nela, o Bichoterapia sofreria drásticas mudanças. Como não se chegou a um consenso entre direção e professor, e receando que

\footnotetext{
${ }^{1}$ Fonte: http://www.deltasociety.org/
} 
tais mudanças colocassem em risco a qualidade do Projeto original, decidiu-se, então, pela suspensão do Bichoterapia. No entanto, a idéia de reiniciar o Projeto na rede pública sempre permaneceu presente. Após várias tentativas, pois se trata de um Projeto não muito convencional, em fevereiro de 2009 foi reiniciado o Bichoterapia, agora com um novo formato, a começar por seu nome: "Bichoterapia - Amigo Especial".

Esse novo local situa-se em um Centro de Ensino Especial, o qual está localizado em Brasília, na Asa Sul. O Centro oferece atendimento a alunos com Necessidades Educacionais Especiais a partir de 14 anos de idade, oriundos de toda a comunidade escolar do DF e que, ainda, não atendem às perspectivas do processo de inclusão nas escolas do ensino regular. A Oficina Bichoterapia Amigo Especial, agora como um novo formato foi implantada nesse Centro como uma oficina motivadora. Passado esse período de adaptações, a oficina segue com o objetivo de ajudar no processo de inclusão dos aluno do Centro. Dito isso, é importante ressaltar que é uma falácia afirmar que os Centros de Ensino Especial seguem o caminho inverso ao da inclusão.

O fato é que, por inúmeros motivos, ainda hoje existem alunos que permanecem em Centros de Ensino Especiais e, cabe a esses Centros, trabalhar para que seus alunos tenham uma educação de qualidade, com suas potencialidades bem trabalhadas, abrindo possibilidades de um melhor viver. Cabe aos professores de Centros de Ensino Especial assumir esse papel e não se acomodarem, crendo que a deficiência leva ao fracasso. Isso leva aos questionamentos dessa pesquisa: estará a Oficina Bichoterapia - Amigo Especial realizando uma atividade que, de fato, que contribua para a inclusão dos alunos com Necessidades Educacionais Especiais? Quais são essas contribuições? 


\section{1-FUNDAMENTAÇÃO TEÓRICA}

\section{1- Inclusão}

Antes de se propor ou de se pensar uma forma de incluir Alunos com Necessidades Educacionais Especiais, deve-se primeiro compreender a definição para Ensino Especial. Conforme pode ser lida na página eletrônica da própria SEDF Ensino Especial é: "Modalidade de educação escolar ofertada na Rede Pública do Distrito Federal para estudantes com deficiência, Transtorno Global de Desenvolvimento (TGD) e Altas Habilidades/Superdotação, de acordo com a recomendação da legislação em vigor".

Para abordar a Educação Inclusiva, tão atual na política nacional, é preciso entendê-la melhor. Vejamos a opinião de alguns autores, citados na apostila Eixo Integrado: Educação e Trabalho (2003, p.190) utilizada na graduação do Curso de Pedagogia para Professores em Início de Escolarização PIE:

STAINBACK (1992):

O conceito de inclusão reflete mais clara e precisamente o que é adequado: todas as crianças devem ser incluídas na vida social e educacional e classe de seu bairro, e não somente colocadas no curso geral.

BONETI (1996):

A educação inclusiva percebe a heterogeneidade como possibilidade de enriquecimento do grupo. A garantia de uma educação de qualidade pra todo implica, entre outros fatores, um redimensionamento na escola no que consiste não somente na aceitação, mas também na valorização da diferença.

MANTOAN (1997):

A inclusão constitui a inserção de uma forma mais radical, completa e sistemática. A inclusão se concilia com uma educação para todos e com um ensino especializado no aluno, mas não se consegue implantar uma opção de inserção tão revolucionária sem enfrentar um desafio ainda maior, o eu recai sobre o fator humano.

SASSAKI (1998):

Uma escola inclusiva seria caracterizada não tanto por um conjunto de práticas e, sim, pelo seu compromisso em desenvolver continuamente a capacidade de acolher uma ampla gama de diferenças individuais entre seus alunos. 
Para fortalecer tal conceituação, dois eventos significativos ocorreram: a Conferência Mundial sobre Educação para Todos, em Jomtiem - Tailândia, em 1990, e a Conferência sobre Educação Especial/Acesso e Qualidade, em Salamanca, Espanha, em 1994. Segundo a Declaração de Salamanca, deve-se buscar (1994, p.18): "desenvolver uma pedagogia centrada na criança, capaz de educar com sucesso todos os meninos e meninas, inclusive os que sofrem de deficiências graves". De acordo com a Política Nacional de Educação Especial (BRASIL/MEC, 1994, p. 18):

"integração é um processo dinâmico de participação das pessoas num contexto relacional, legitimando sua interação nos grupos sociais. A integração implica reciprocidade".

Há que se mencionar, contudo, que com a Declaração de Salamanca ${ }^{2}$, Resolução da Organização das Nações Unidas (ONU), assinada na cidade espanhola de Salamanca, em 1994, e que aborda os princípios, políticas e práticas relativos à Educação Especial, as políticas públicas voltadas para essa área passaram a ser tratadas de modo mais sério e consistente, graças à chancela da ONU. Inclusive, a Declaração de Salamanca avança quando aumenta a "clientela" que pode se beneficiar da Educação Especial, ampliando ainda mais o raio de ação das propostas governamentais que têm como alvo projetos como a "Educação para todos". É um avanço significativo nesse campo, mas que precisa ser operacionalizado através da capacitação de mais profissionais que tenham interesse em trabalhar com a problemática da Educação Especial, inclusive com propostas pedagógicas por parte dos profissionais já inseridos nesse campo.

O Brasil possui um arcabouço de leis relacionadas à educação considerado muito avançado até para países do chamado primeiro mundo. A Lei de Diretrizes e Bases da Educação Nacional (LDBEN - Lei 9394/96) e as Diretrizes Nacionais para a Educação Especial na Educação Básica (Resolução CNE/CEB no 2/2001) significam avanços importantes na proposta de incluir todas as crianças e jovens no processo de aquisição de educação escolar (Educação para Todos (EPT) - um programa do Governo Federal que conta com o apoio da UNESCO). No que diz

\footnotetext{
${ }^{2}$ Fonte: http://portal.mec.gov.br/seesp/arquivos/pdf/salamanca
} 
respeito ao conceito de inclusão de pessoas com necessidades educacionais especiais, a Resolução CNE/CNB no 2/2001 é um suporte muito valioso para a organização da chamada educação especial/inclusiva, inclusive incentivando a discussão de novas propostas pedagógicas e a formação e capacitação de professores que se interessam por esse tipo de educação.

A questão da integração/inclusão, como vem sendo tratada hoje, ainda está longe de encontrar soluções aceitáveis, mas é inegável que só o fato de estar sendo colocada em debate já é um grande avanço. Em relação à abordagem dessa problemática, é muito útil citar Vygotsky (1995, p. 61):

\begin{abstract}
A humanidade sempre tem sonhado com o milagre religioso: que os cegos vejam e os mudos falem. É provável que a humanidade triunfe sobre a cegueira, a surdez e a deficiência mental. Porém a vencerá no plano social e pedagógico muito antes que no plano médico-biológico. É possível que não esteja longe o tempo em que a pedagogia se envergonhe do próprio conceito de "criança com defeito" (...) O surdo falante e o trabalhador cego, participantes da vida geral, em toda a sua plenitude, não sentirão sua deficiência e não darão motivo para que os outros a sintam. Está em nossas mãos o desaparecimento das condições sociais desses defeitos, ainda que o cego continue sendo cego e o surdo continue sendo surdo.
\end{abstract}

Teorias, leis, práticas... Já se sabe o quanto é importante se ter uma sociedade inclusiva. Buscam-se, sempre, maneiras de melhorar e acelerar esse processo. Paralelamente, e não menos importante, não de pode ignorar que muitos, ainda, não foram atingidos por esse processo. A questão é: o que fazer para não deixar que essas pessoas caiam em uma rotina desestimulante, levandoas ao descontentamento, indisciplina e até à evasão escolar?

\title{
1.2- Atividade Assistida por Animais (AAA)
}

A ideia de que animais pudessem atuar como coadjuvantes em um processo pedagógico e emocional vem ganhando força em tempos recentes e essa tese foi desenvolvida, pela primeira vez no Brasil, pela Dra. Nise da Silveira, psiquiatra de renome e discípula de Carl Gustav Jung, que foi a pioneira nas 
pesquisas sobre as relações emocionais que se criam entre pacientes e animais. Não bastasse isso, a observação empírica mostra que os animais domésticos são providos de afeto, sendo fontes de carinho para os seus donos e companheirismo para os seres humanos, em geral, há séculos, bem como trazendo-lhes benefícios como a proteção e a vigilância de rebanhos, auxiliares em caçadas e exterminadores de pragas domésticas, como ratos e baratas. A esses conhecidos benefícios recentemente se agregaram os de ordem psicológica e pedagógica.

Um fato importante na área educacional com a utilização de animais domésticos ocorreu, no Rio de Janeiro em setembro de 2001, quando foi aprovada na, "9a Conferência Internacional das Interações Homem-Animal", a "Declaração da IAHAIO (Organizações de Interação Homem Animal - contida no site: sobre animais nas escolas. Apesar de haver algumas discordâncias entre profissionais da área .

A mais conhecida das terapias que faz uso de animais, no Brasil, é a Equoterapia $^{3}$, a terapia com cavalos. Muito útil ao processo de interação, essa modalidade de terapia facilita o restabelecimento de pessoas com deficiências físicas, problemas mentais e muitas dificuldades relacionados à motricidade. $\mathrm{A}$ equoterapia, além desses benefícios, é uma atividade prazerosa e muito estimulante e que, segundo os seus próprios praticantes, também estimula a autoestima e a autoconfiança. Contudo, a atividade com o uso de animais não se restringe aos cavalos, podendo utilizar-se de, entre outros, aves, peixes, coelhos, gatos e cães, sendo que estes últimos são os mais indicados uma vez que possuem maior sociabilidade e fácil interação com os humanos, características que facilitam muito o trabalho dos profissionais, trazendo melhores resultados para os atendidos.

Como foi dito anteriormente, esses benefícios já são conhecidos no meio cientifico há algum tempo e já há algumas fontes literárias que abordam esse

\footnotetext{
${ }^{3}$ Fonte: http://www.equoterapia.org.br/
} 
assunto. Dignos de menção são os depoimentos de profissionais como a Dra. Fuchs $^{4 \text { Fonte : }}$

Temos uma necessidade psicológica de nos relacionar com os animais que não pode ser satisfeita pelo ser humano (...). O contato dos seres humanos com os bichos faz o corpo liberar endorfina (um analgésico natural.

A respeito da biografia dessa importante médica veterinária e psicóloga, abaixo segue uma breve descrição de suas ideias e trabalhos realizado:

A médica veterinária e psicóloga Hannelore Fuchs é uma das precursoras no uso de animais para interagir com crianças, adolescentes e idosos em hospitais ou instituições. Fundadora da Associação Brasileira de Zooterapia (Abrazoo). Hannelore revela que o trabalho é mais do que uma distração para os assistidos. "Constatam-se diminuição de medicamentos, menos incidência de depressão e aumento da sobrevida de enfartados" ${ }^{4}$, cita. $\mathrm{O}$ atendimento a adultos e crianças é feito de maneira diferenciada, pois as crianças são mais receptivas. "O mundo delas é diferente do mundo dos adultos. É mais simples. $O$ animal entra com facilidade" ${ }^{\prime \prime}$ diz a Dra. Fuchs. A psicóloga explica, ainda que, na atividade, o animal é um facilitador, um canal através do qual é possível um ser humano chegar a outro ser humano. "É oferecido um animal comum, para ser tocado, percebido e apreciado. Quando não há afeto, o trabalho segue o caminho da impessoalidade. É preciso ter um objetivo, muitas vezes é necessário driblar o isolamento pessoal. E o animal distingue ${ }^{4}$."

Os benefícios do convívio do homem, não só com os animais domésticos, mas com todos os seres vivos, podem trazer alguma redução do estresse diário a que os moradores de grandes cidades estão sujeitos. Recentemente, pesquisadores relataram a melhora psicológica e física do convívio homem e animal de estimação, revelando que a maioria dos proprietários de cães e gatos afirmou que a qualidade de vida melhorou após a introdução dos animais de

\footnotetext{
${ }^{4}$ Fonte: http://www.humaniversidade.com.br/boletins/entre_o_ceu_inferno.html

${ }^{4}$ Fonte: http://www.humaniversidade.com.br/boletins/entre_o_ceu_inferno.html
} 
estimação, sendo observada, também, uma diminuição das tensões entre os membros da família, aumentando a compaixão, inclusive no convívio social (Barker, 1998). Dados do Instituto Brasileiro de Geografia e Estatísticas (IBGE), ano-base 2002 , apontam que $64 \%$ da população brasileira das classes A, B e C têm um animal de estimação dentro de casa. A Dra. Silveira (1998) relata a experiência de como os animais domésticos podem desempenhar um importante papel de coadjuvantes no tratamento de pacientes com transtornos psiquiátricos. Desde já há algum tempo, vem se acumulando um conhecimento ainda modesto sobre a relação humano - animais domésticos, em nível familiar e social, bem como o significado dos "pet" (animais domésticos), na vida dos seres humanos. E, com isso, podem-se desenvolver técnicas utilizando cães como ajudantes em atividades individuais e familiares (Coutinho et all, 2004). Segundo esse autor a interação homem e animal de estimação, principalmente com os cães, tem sido benéfica para a saúde do ser humano, tanto para a saúde mental, como para a saúde física. Esses benefícios vão desde o relaxamento e o carinho que o animal de estimação oferece a pessoa, até a zooterapia e os serviços prestados pelos cães aos deficientes físicos (cegos, p. Ex.).

O Filme Jornada da Alma, conta a história da psicanalista russa de origem alemã Sabina Spielrein (1885-1942), paciente do eminente psicanalista Carl Gustav Jung no hospital Burghölzli e, posteriormente, sua discípula. A personagem principal realiza em seu Jardim de infância, localizado em Moscou e conhecido como "A Enfermaria Branca" (suas paredes e as mobílias eram na cor branca), uma das primeiras sessões de AAA conhecidas. Após inúmeras tentativas fracassadas de estabelecer contato com uma criança autista, a psicanalista utiliza como recurso didático um símio. A barreira, até então intransponível, começa a desaparecer. No drama, o menino autista, já adulto, relata os fatos acontecidos.

Como já foi mencionado, a Dra. Nise foi a pioneira no Brasil na utilização de animais como coadjuvantes na terapia de pacientes com dificuldades no contato com o mundo exterior. É muito significativo o relato que a Dra. Nise faz do 
encontro entre um de seus pacientes e os vínculos emocionais que se formaram. Segundo Silveira (1981, p. 81):

Desde a adoção da pequena cadela Caralâmpia (1955) por um doente que freqüentava uma de nossa oficinas, verifiquei as vantagens da presença de animais no hospital psiquiátrico. Sobretudo o cão reúne qualidades que o fazem muito apto a tornar-se um ponto de referência estável no mundo externo. Nunca provoca frustrações, dá incondicional afeto sem nada pedir em troca, traz calor e alegria ao frio ambiente hospitalar. Os gatos têm um modo de amar diferente. Discretos, esquivos, talvez sejam muito afins com os esquizofrênicos na sua maneira peculiar de querer bem.

O Professor de veterinária da Universidade de Zurique e presidente da Associação Internacional IAHAIO, Dennis Turner, acredita que os animais nos trazem mais benefícios do que as alegrias domésticas já conhecidas: "A companhia de animais beneficia não apenas deficientes ou portadores de doenças graves, mas também o cidadão comum seja qual for a sua renda familiar", diz Turner ${ }^{5}$ :

Quanto aos grupos de pessoas com Necessidades Educacionais Especiais que podem receber A Assistida por Animal (AAA)), há estudos que comprovam os benefícios advindos da utilização de animais domésticos como auxiliares.

Ainda segundo Turner, na mesma entrevista ${ }^{5}$ :

Donos de animais de estimação geralmente têm baixo nível de colesterol, um dos fatores que pode levar a um ataque do coração. Um estudo publicado pelo British Journal da Royal Society of Medicine indica que, ao adquirir um cão ou gato, o dono reclama com menos freqüência de pequenos problemas de saúde e desfruta de melhor qualidade de vida do que pessoas sem animais de estimação. Este efeito dura, no mínimo, 10 meses depois da aquisição - que foi a duração da pesquisa - para os donos de cachorros. Logo, não estamos falando de um "efeito novidade" que vale apenas para um breve período de tempo depois da aquisição do animal. Pesquisas médicas de larga escala na Austrália concluíram que donos de animais de estimação se consultam com menor frequência com clínicos gerais e requerem menos medicação do que as pessoas sem animal de estimação. O estudo que apresentarei na 9a Conferência mostra que o dono de gato - e o de cachorro com menos intensidade - estão menos sujeitos a gastar dinheiro com saúde do que os 'sem-animal'. Já publiquei estudos que tratam de como o gato pode reduzir sentimentos de depressão, solidão e ansiedade - sentimentos que todos nós temos mais

\footnotetext{
${ }^{5}$ Fonte: http://www.arcabrasil.org.br/
} 
cedo ou mais tarde sem estar clinicamente doente. Animais de companhia também se mostraram bastante prestativos para crianças tanto em casa quanto na escola. Eles aumentam a auto-estima da criança, melhoram sua integração na sala de aula, incentivam o contato social com outras crianças e aumentam sua vontade de aprender. Há, ainda, casos bem-sucedidos de animais como auxiliares interagindo com doentes psíquicos que não se comunicam; crianças hiperativas ou agressivas; portadores de síndrome de Down; pacientes com mal de Alzheimer; pacientes com problemas neurológicos e deficientes físicos.

\subsection{1-. A Prática Pedagógica e a Utilização de Animais Domésticos}

Há inúmeras práxis pedagógicas que utilizam animais domésticos, e podese destacar a aula passeio: Célestin Freinet, um professor primário francês que provocou um grande movimento pedagógico no século $\mathrm{XX}$, foi um educador que destacou a importância do contato da criança com a natureza, os animais e as plantas, nas chamadas "aulas passeio". Nelas, a intenção é sair dos limites físicos da escola, porque "o interesse das crianças estava lá fora, assim era preciso colocá-las em contato com a natureza e com os mundos social e cultural, levandoas para onde se sentiam felizes: lá fora” (SAMPAIO, 1989, p. 15)". "(...) A força da natureza sensibilizava cada uma das crianças de acordo com sua personalidade, sua percepção de mundo e sua curiosidade. (...) Era a vida entrando na sala de aula." (SAMPAIO, 1989, p. 15-16)

Dos pedagogos mais contemporâneos, podemos destacar Madalena Freire, Pedagoga professora de Educação Infantil, de Classes Populares e formadora de professores. Filha e seguidora de Paulo Freire. Em sua obra "A paixão de conhecer o mundo", explicita, com muitos detalhes, os trabalhos que desenvolveu envolvendo os animais: do estudo da metamorfose da lagarta em borboleta, ao pintinho e a galinha e sua comparação com o corpo humano, passando pelo estudo de cobras e aranhas, que culminou na dissecação de uma cobra, entre outros. Esse trabalho de convivência com os animais permitiu que juntos, professora e alunos, fossem conhecendo e descobrindo a si mesmos e ao mundo. "Todo esse processo de busca e descobertas nos desvela o processo educativo, 
'a educação como um ato de conhecimento', que nunca se esgota, que é permanente e vital' (FREIRE, 2001, p. 54).

Nos Parâmetros Curriculares Nacionais/Temas Transversais: Meio Ambiente, é de se destacar: "a apreensão do mundo por parte da criança não se dá de forma linear assim, é preciso oferecer-lhes, além da maior diversidade possível de experiências, uma visão abrangente que englobe diversas realidades e, ao mesmo tempo, uma visão contextualizada da realidade ambiental" (BRASIL, 1997, p. 48).

Alguns dos conteúdos previstos pelos PCNs sobre o meio ambiente são:

3. - Cuidados necessários para o desenvolvimento das plantas e animais.

b) Valorização e proteção das diferentes formas de vida.

c) Cumprimento das responsabilidades de cidadãos, com relação ao meio ambiente.

d) Noções sobre procedimentos adequados com plantas e animais.

\subsubsection{A Utilização de Animais Domésticos no Processo de Ensino Aprendizagem}

O processo de ensino, ou as relações de ensino, se constitui nas interações pessoais e difere-se da tarefa de ensinar que é a instituída pela escola, com base nas relações de ensino (SMOLKA, 2001). Assim, relações de ensino dizem respeito às interações sociais intencionais nas quais alguém aprende algo com um outro alguém, em algum momento, em algum lugar, para alguma coisa. Tais relações podem ou não acontecer dentro da escola. Já a aprendizagem é um processo "necessário e universal, para que se desenvolvam na criança [as] características humanas não-naturais, mas formadas historicamente" (VIGOTSKI, 2001, p.115). Nessa concepção, “(...) a aprendizagem da criança começa muito antes da aprendizagem escolar." 
"A aprendizagem escolar nunca parte do zero. Toda aprendizagem da criança na escola tem uma pré-história"(VIGOTSK, 2001, p. 109 - grifos do autor). Leontiev (2001) destaca que o "desenvolvimento da psique da criança é a sua própria vida e o desenvolvimento dos processos reais desta vida" (p. 63), ou seja, o desenvolvimento da atividade na criança depende das suas condições concretas de vida. Sendo assim, as AAA são importantes auxiliares no desenvolvimento da aprendizagem escolar da criança,entre outros fatores, pois, segundo Martins (2006, pp. 254-255):

- Serem elos de ligação entre a aprendizagem e os estudos acadêmicos, proporcionando a conciliação com as diferentes áreas do saber;

b) irem ao encontro da formação e da conscientização em vista da construção de atitudes de respeito, responsabilidade e preservação à vida de todos os seres vivos e do meio ambiente;

c) servirem de base de apoio constante, oferecendo consolo e aceitação incondicional;

d) satisfazerem a curiosidade, proporcionarem satisfação e inserirem mais facilmente no currículo escolar os temas transversais (meio ambiente,ética, educação de sentimentos etc.) ajudando no aprendizado de conteúdos procedimentais e atitudinais;

e) representarem um fator de motivação para a aprendizagem e fortalecerem a auto-confiança, a socialização, a comunicação e os valores da cidadania.

\subsection{3 - Conhecendo a Oficina Bichoterapia- Amigo Especial}

A Oficina Bichoterapia - Amigo Especial, surgiu da necessidade de se desenvolver um trabalho que seguisse o que é pregado em toda a legislação (anteriormente mencionada) que rege a Educação Especial no Brasil, bem como 
da observação de que os animais domésticos, de fato, podem, durante o processo pedagógico, "capturar" a atenção de alunos já desestimulados pela utilização de propostas que não foram, de algum modo, adequadas às suas reais necessidades.

Os alunos que são atendidos na oficina (total de 30 alunos), são avaliados por uma equipe multidisciplinar, de acordo com suas necessidades, especificidades e a modulação da oficina. Todos os animais que participam das atividades passam por testes comportamentais e de saúde, não representando qualquer risco ou ameaça aos participantes. A preocupação de sua idealizadora sempre foi o bem estar de todos os envolvidos, proporcionando um ambiente físico adequado (amplo, arejado, higienizado) e sempre seguindo as normas da “Declaração da IAHAIO”, acima já citada, sobre animais nas escolas.

A proposta da Oficina Bichoterapia - Amigo Especial é oportunizar um atendimento diferenciado aos seus alunos, com atividades que possibilitem 0 desenvolvimento de suas potencialidades, promovendo momentos de alegria e prazer, sempre acreditando na possibilidades de atingir seus alunos, acreditando que com essa prática educacional estará contribuindo para a inclusão social de seus alunos em uma sociedade que, infelizmente, ainda carece de mais propostas inclusivas. Como disse De Carlo (2006):

\begin{abstract}
Em geral, quando matriculamos uma criança com Síndrome de Down na escola, esperamos com base nas prescrições médicas, que o seu desenvolvimento intelectual apresente perdas em função de aspectos marcados pelas determinações genotípicas. Contudo, algumas pesquisas revelam que essa forma de se posicionar é equivocada, pois o diagnóstico possui limitações e os sujeitos, muitas vezes, rompem com as expectativas esperadas,apresentando um desenvolvimento mental muito mais avançado do que aquelas indicadas nas avaliações quantitativas.
\end{abstract}

\title{
Espaço Físico
}

Apesar de ter um espaço físico amplo, o Centro não possuía um local disponível, nem tampouco adequado, para a Oficina. Foi oferecida uma sala que

\footnotetext{
${ }^{6}$ Fonte: http://www.petsuper.com.br/interacao.htm
} 
estava sendo usada como depósito. Esse espaço estava praticamente abandonado, devido ao calor intenso que ali fazia e de possuir uma estrutura física inadequada. O desafio foi aceito, sabendo-se, também, do fato de que não seria liberada nenhuma verba para a reforma da sala.

Devido à boa repercussão da oficina, - mesmo em tais condições, a Bichoterapia já estava sendo colocado em prática - não foi difícil conseguir ajuda para a reforma da sala. Com doações feitas pela comunidade, a ajuda de amigos, professores e muito trabalho, em pouco mais de um mês aquele espaço, que ninguém queria na escola, tornou-se um lugar amplo, agradável e adequado para a oficina, digno de uma escola de altíssima qualidade.

Passados alguns meses da inauguração da oficina, e apesar do acordo feito com a direção que dizia que durante a fase de experiência só aconteceria no turno vespertino, e somente em 2010 passaria para o matutino, no mesmo ano, atendo aos pedidos dos pais e professores, e com o aval da direção e da regional de ensino, $o$ atendimento foi ampliado para os dois turnos.

\section{Animais da Oficina}

Os animais da Oficina são avaliados semestralmeste, tanto no que diz respeito à saúde quanto ao comportamental. No início deste ano a Oficina Bichoterapia - Amigo Especial firmou uma importânte parceria com o Hospital Veterinário da Unb e, desde então, todos os animais da Oficina passaram a ser atendidos, pagando, para isso, apenas uma taxa referente ao material utilizado (seringas, remédios, etc.). A responsabilidade em cuidar dos animais nos finais de semanas, feriados e férias escolares fica a cargo da professora da Oficina e de alguns funcionários da escola. 
São animais da Oficina:

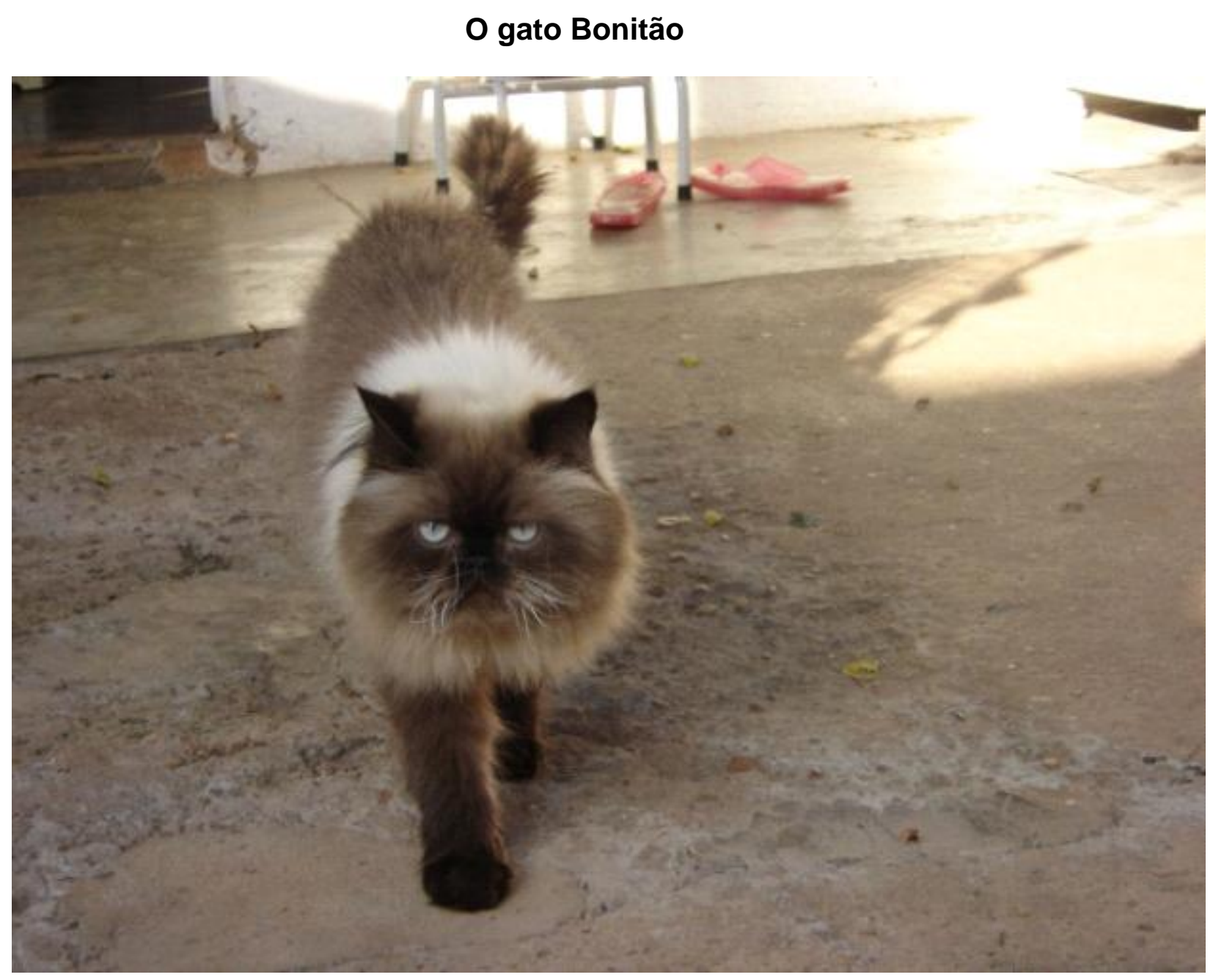




\section{O casal de coelhos Brad e Angelina}

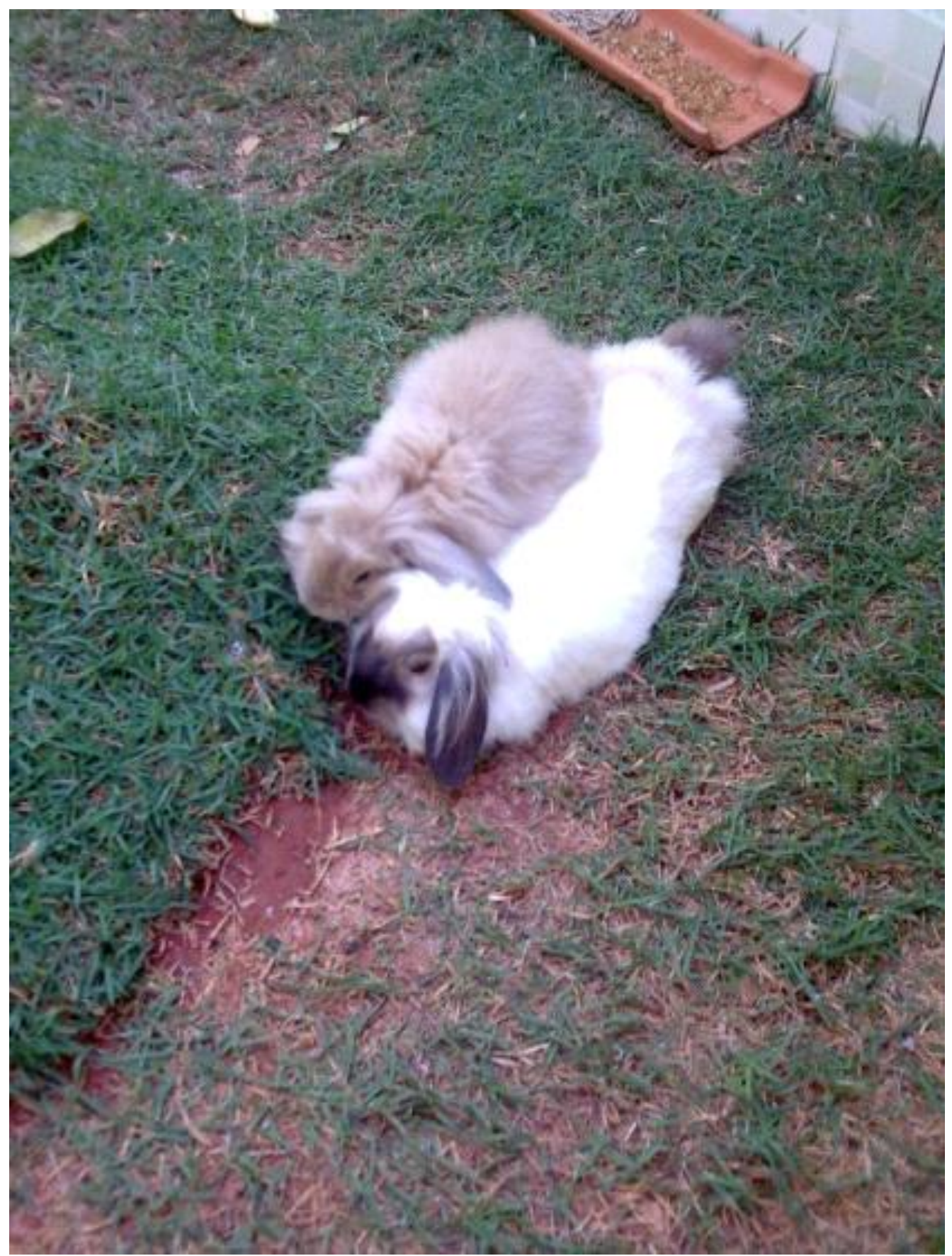


O Cachorro Sigmund Freud, o "Sig"”

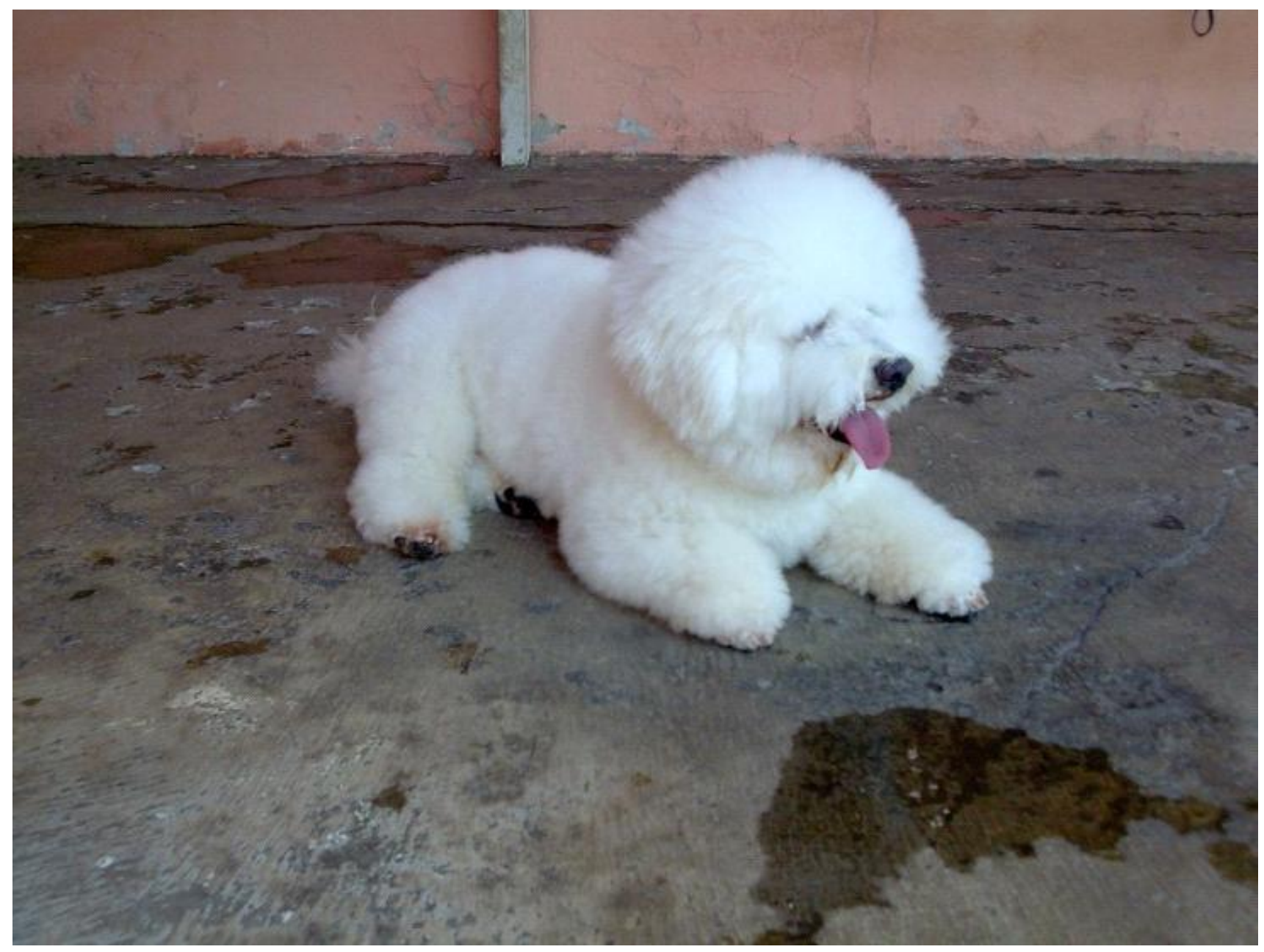


O Galo Zé e a Galinha Zefinha

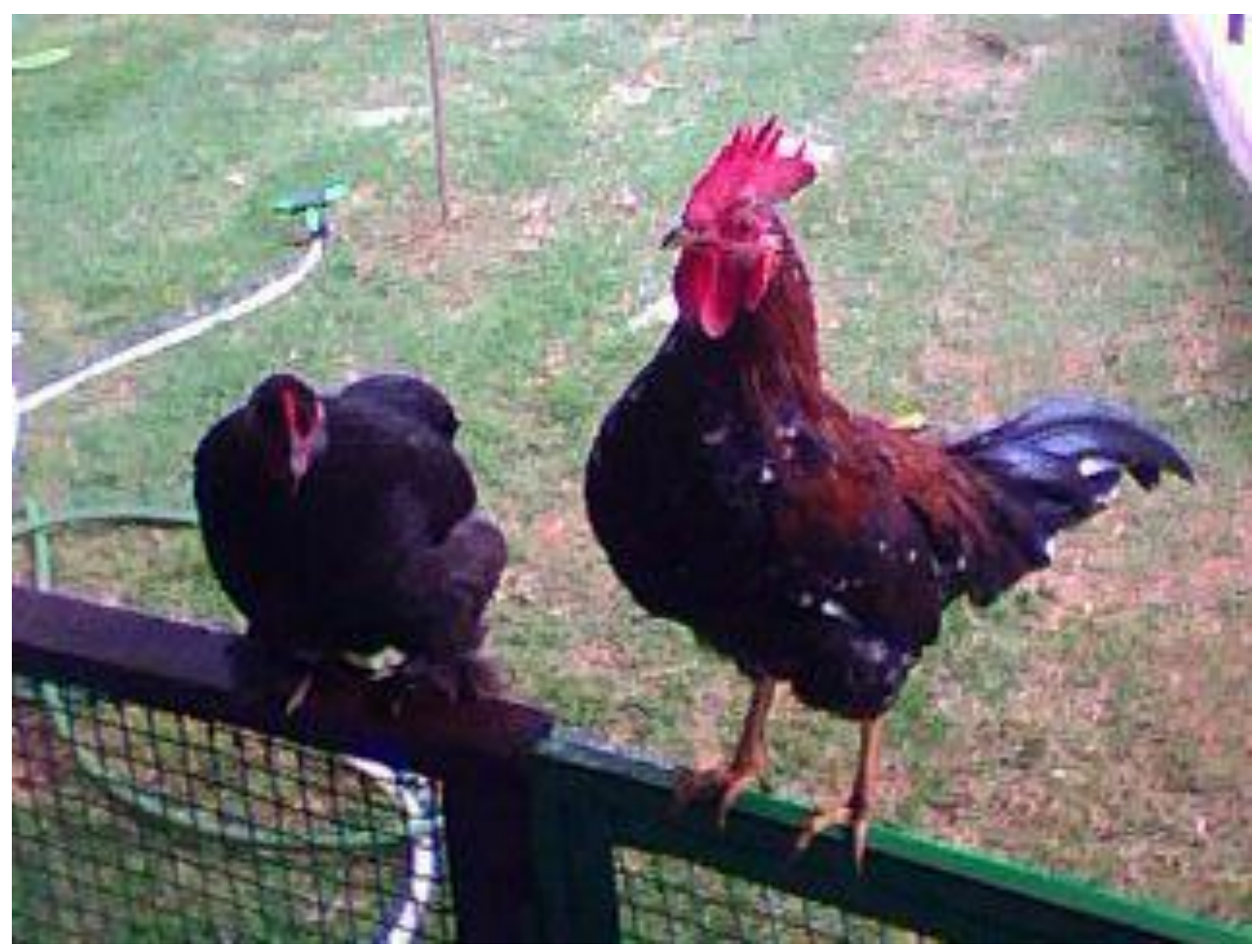


Conhecendo, um pouco, na prática, a Oficina - Bichoterapia-Amigo Especial Conteúdos com significados, de acordo com o interesse e a vivência do aluno.

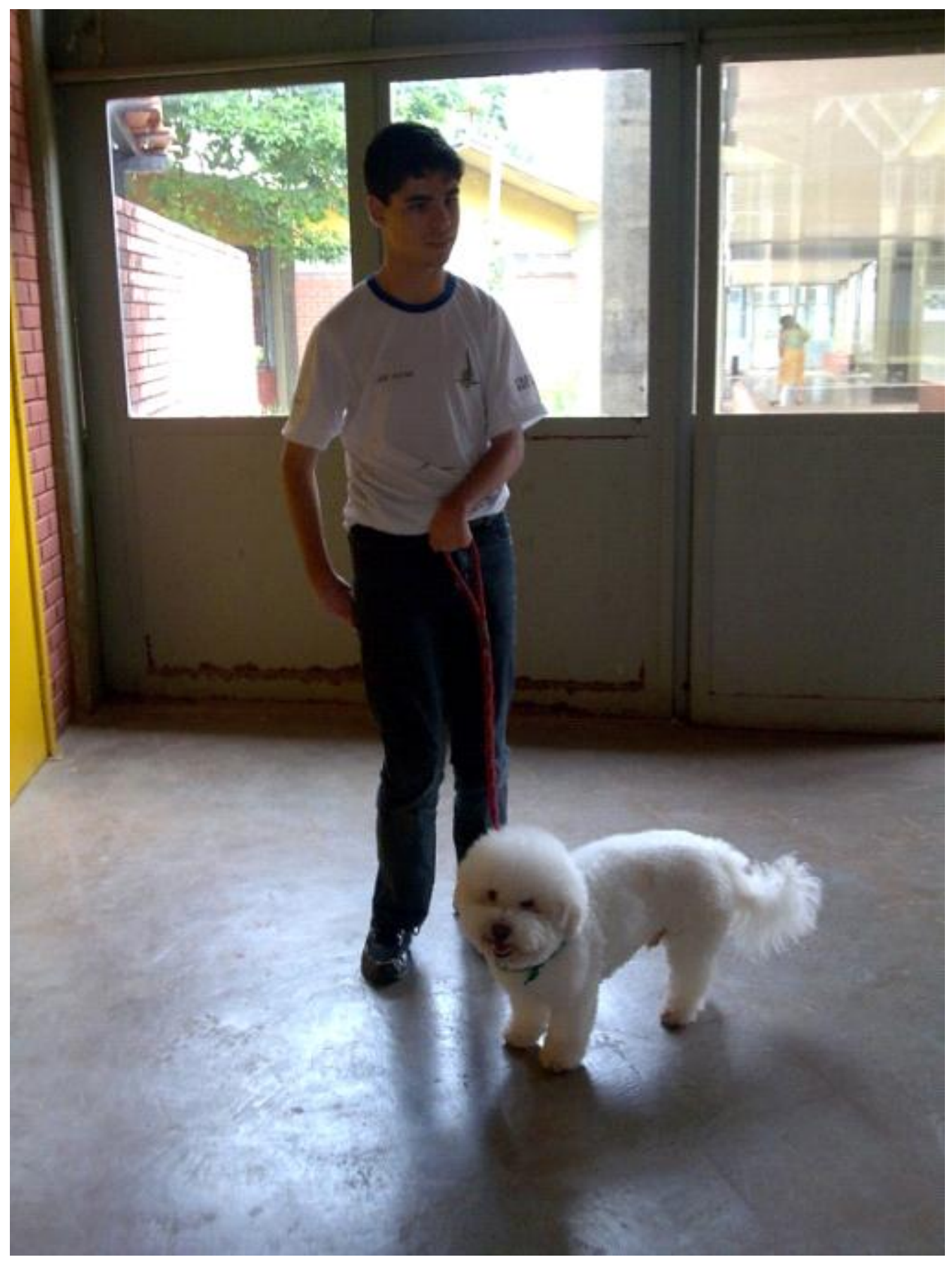




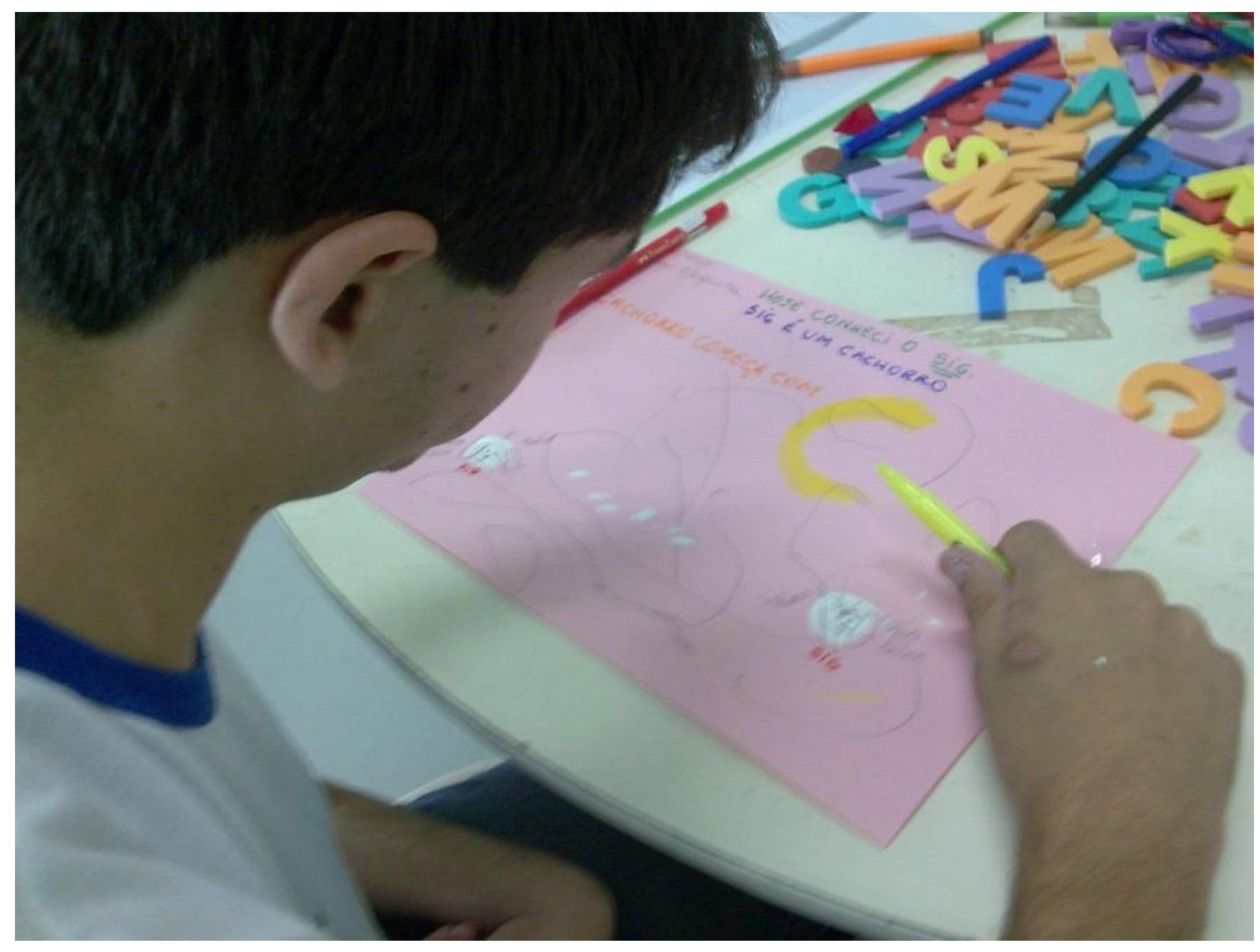




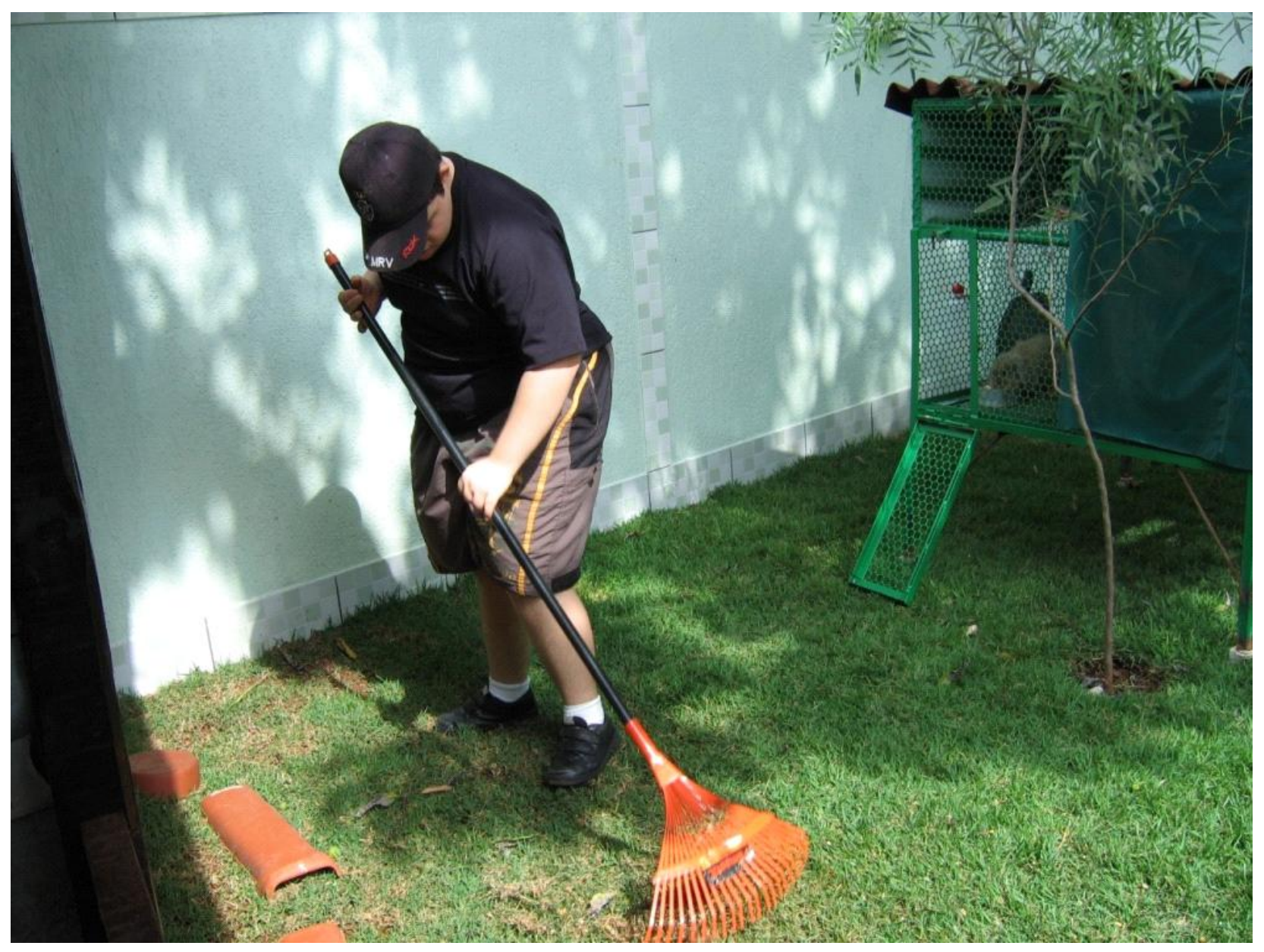




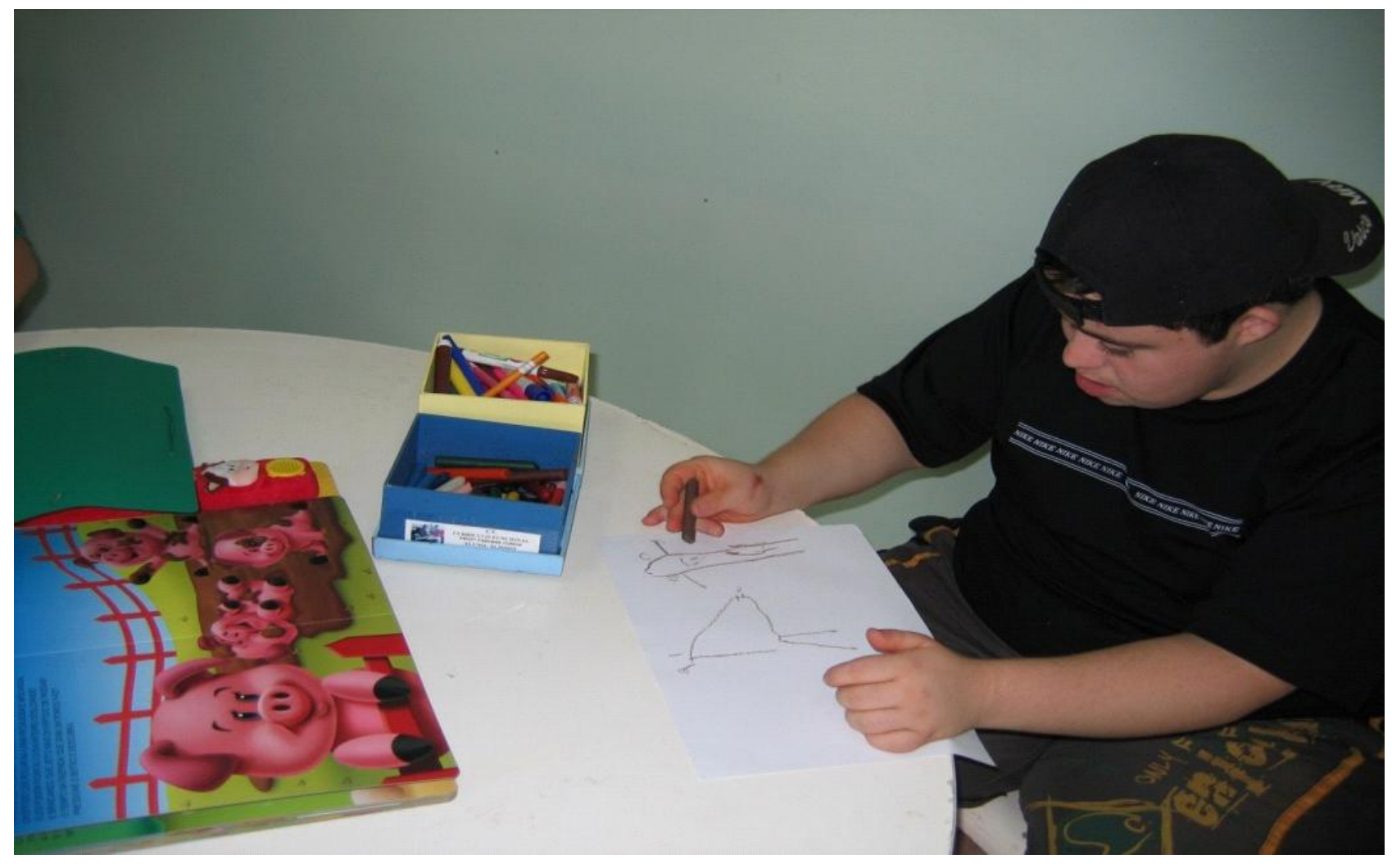


Estimulando a coordenação motora, aprendendo a cuidar dos animais e a respeitar e amar todas as formas da natureza.

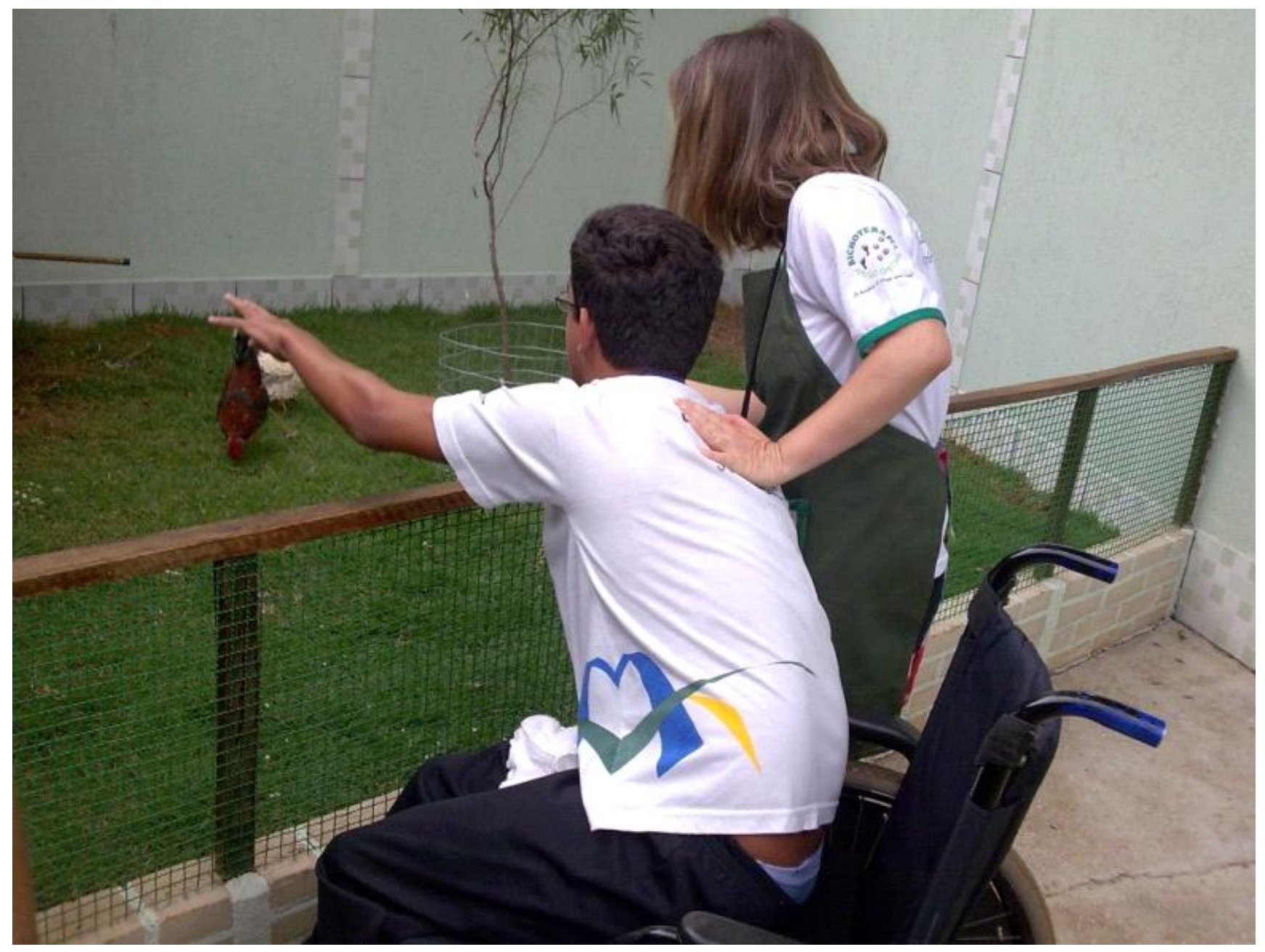




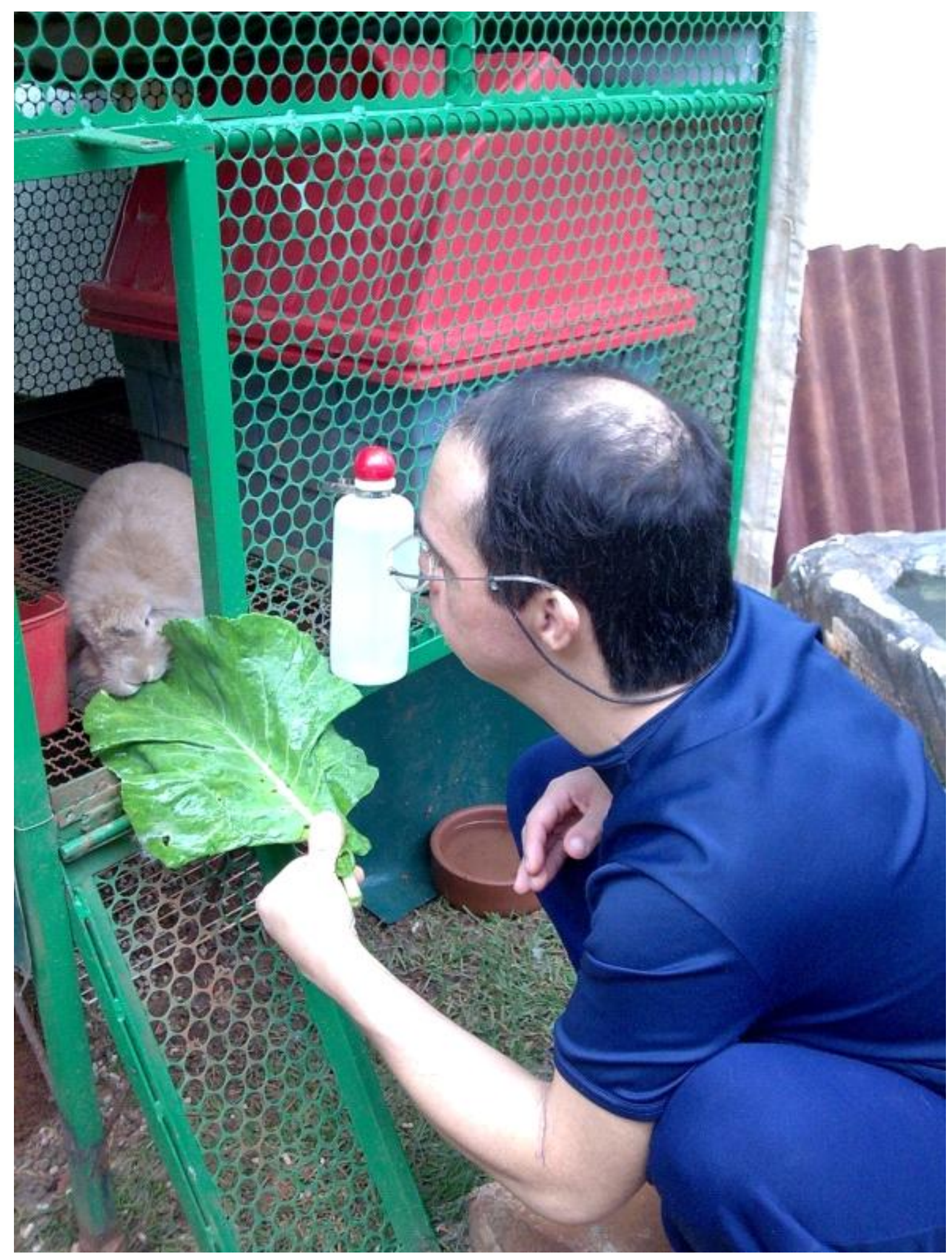




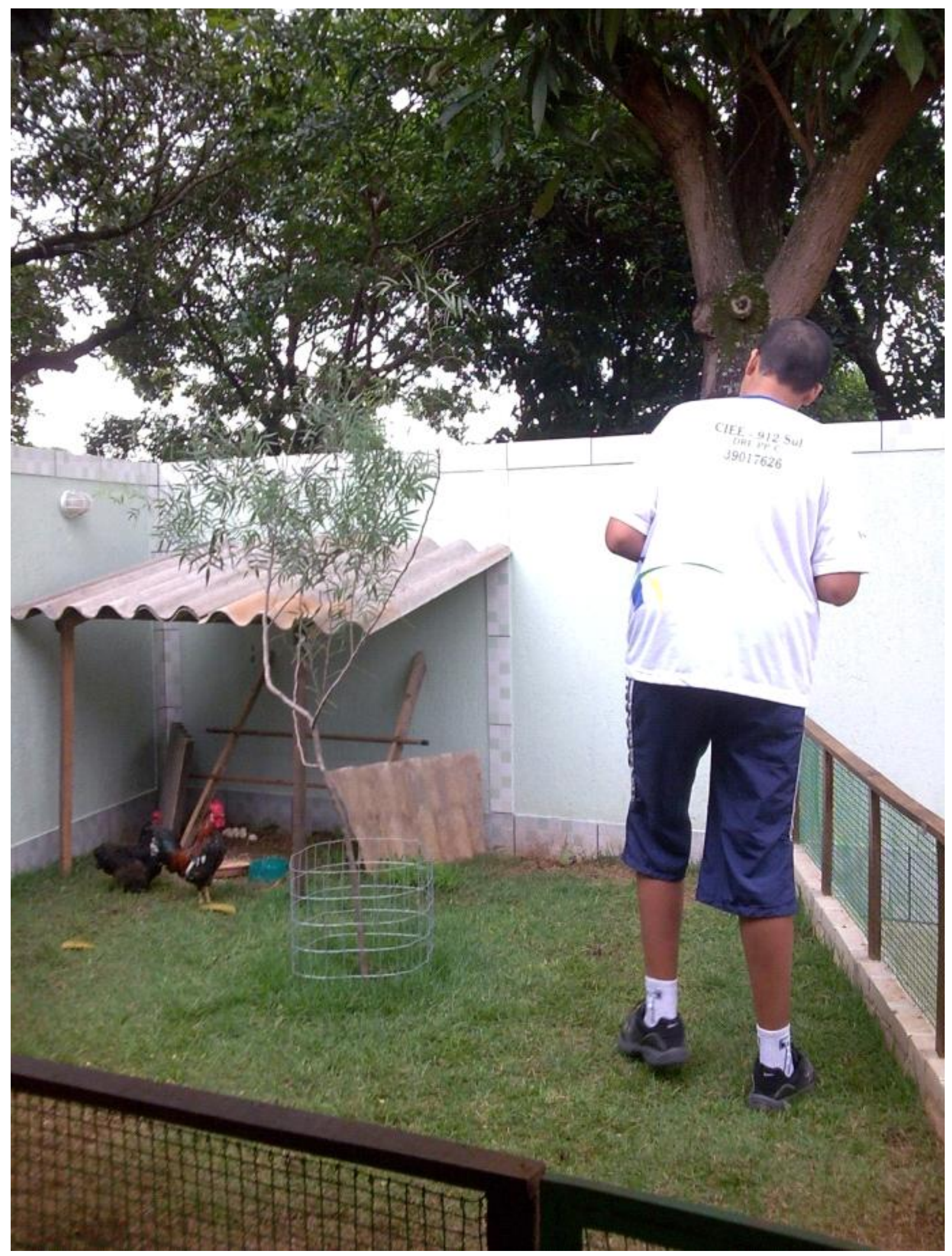




\section{Estabelecendo Vínculos}

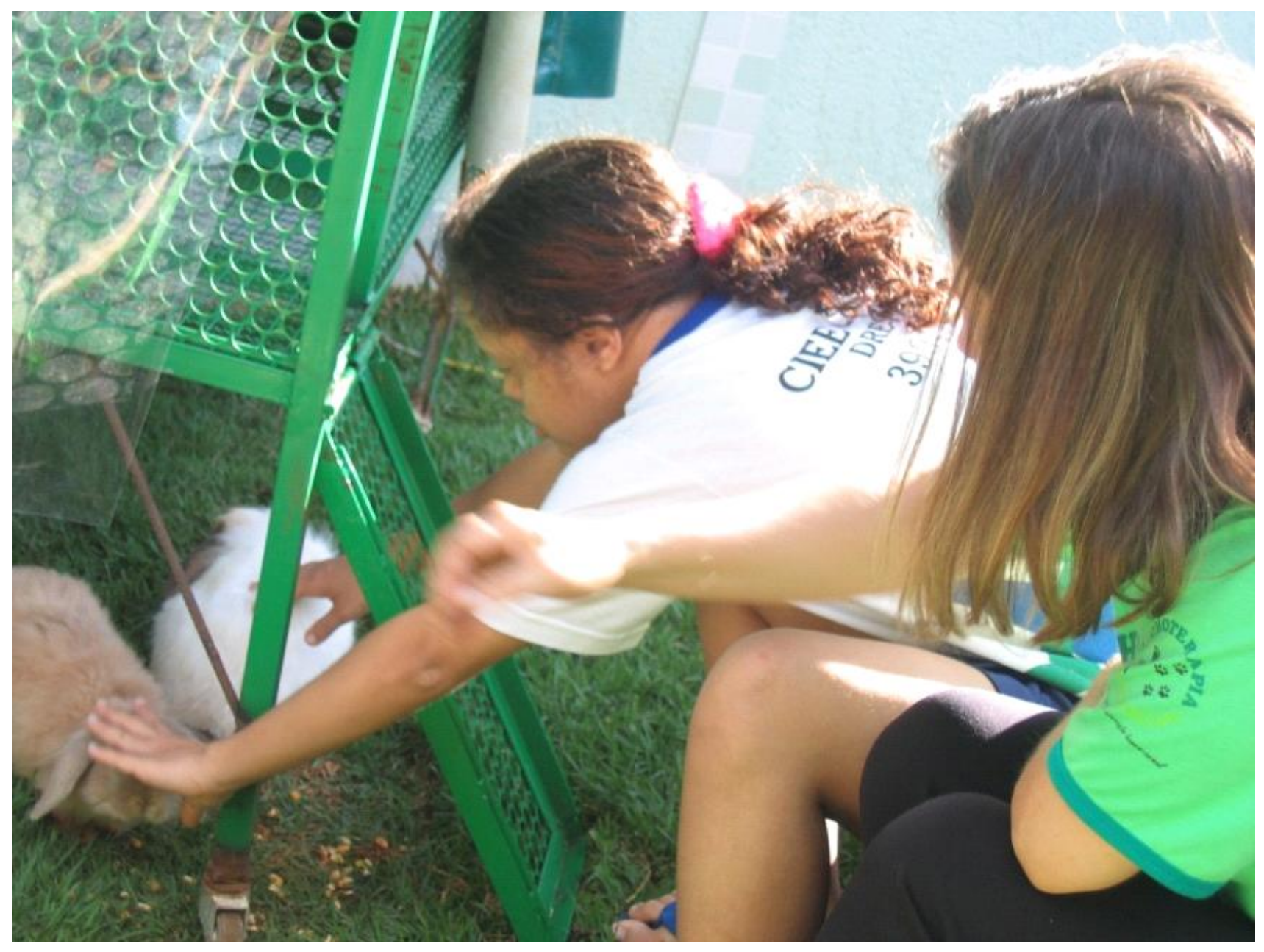




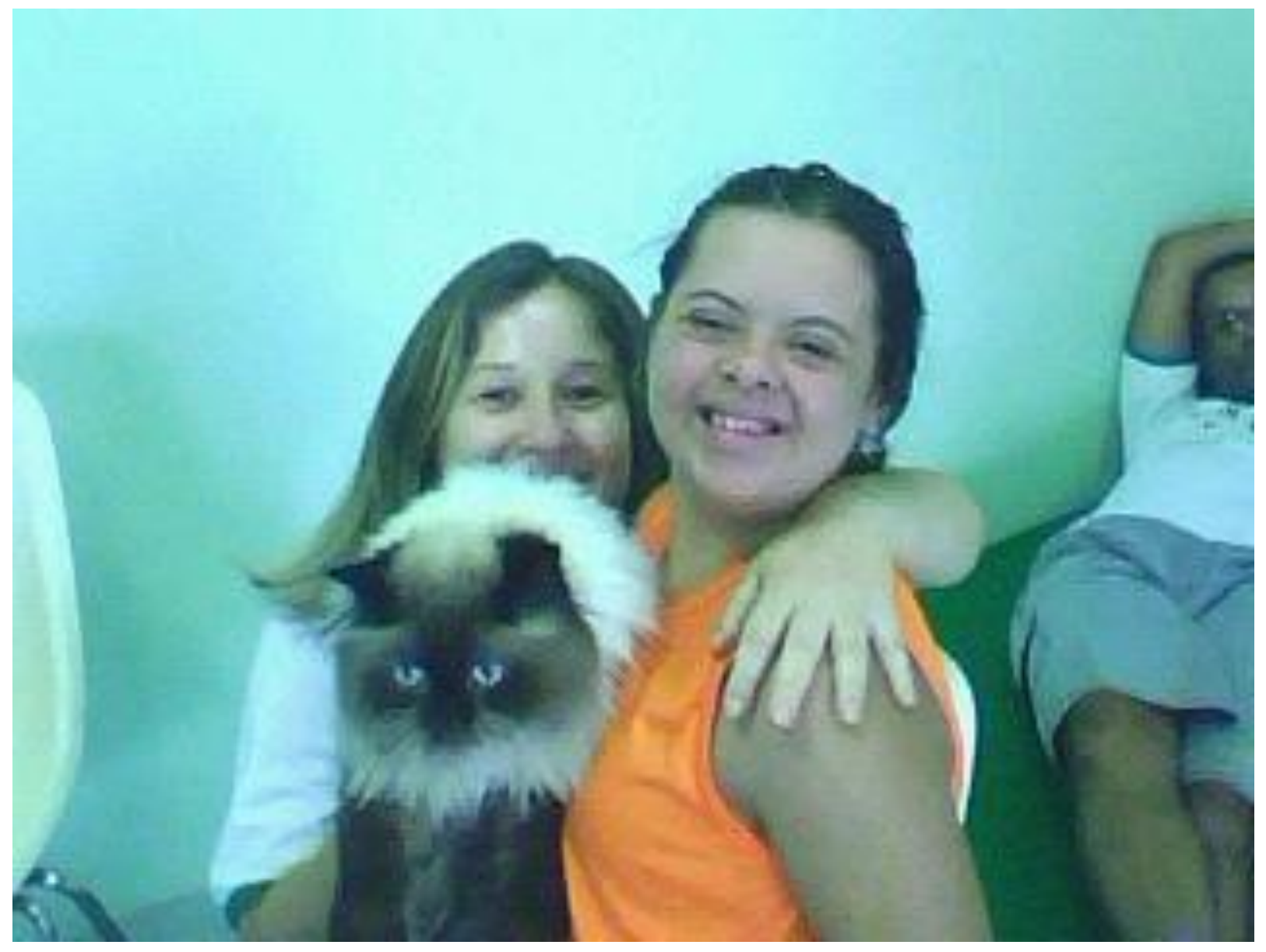




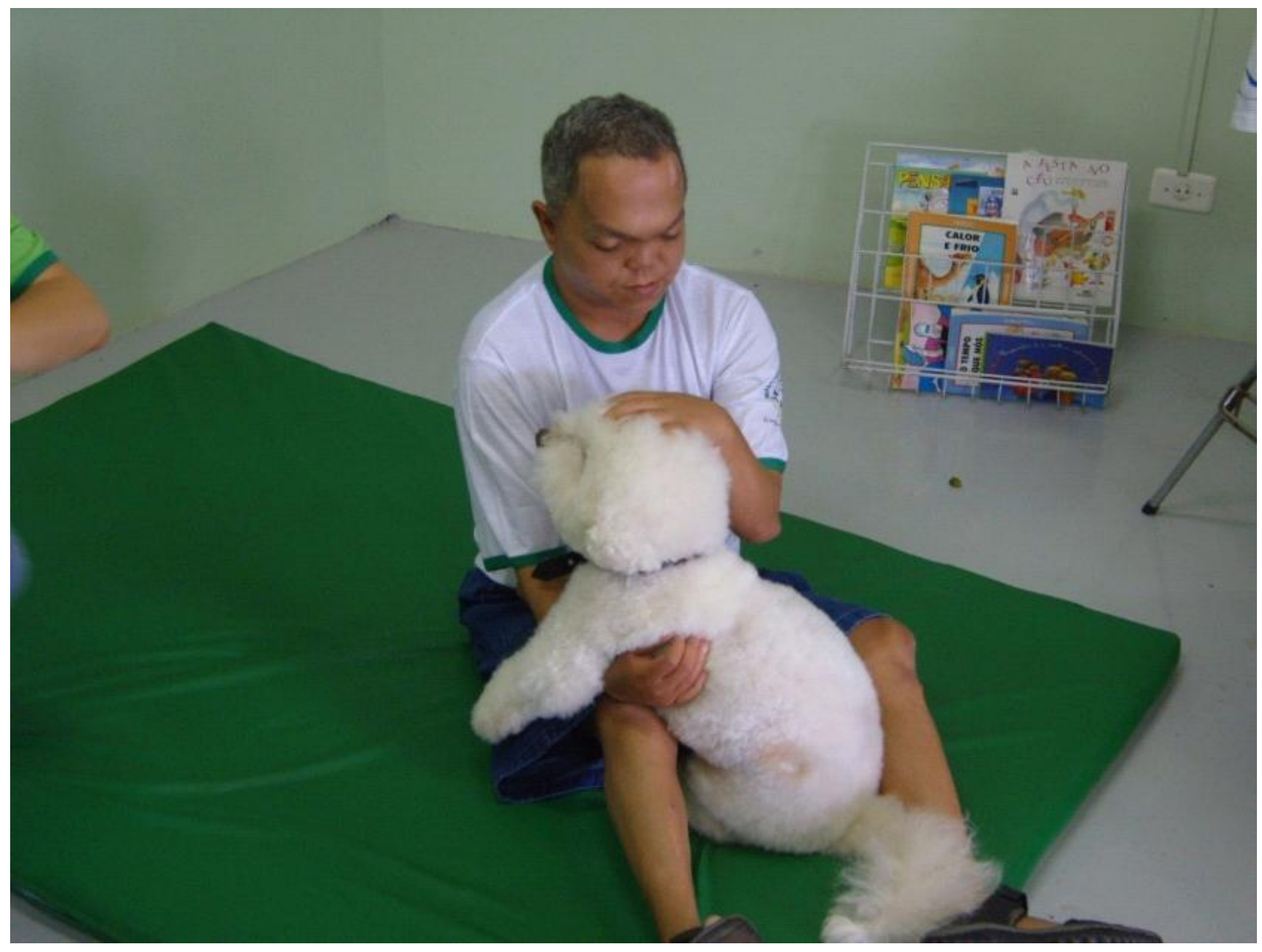




\section{Capacitação Profissional}
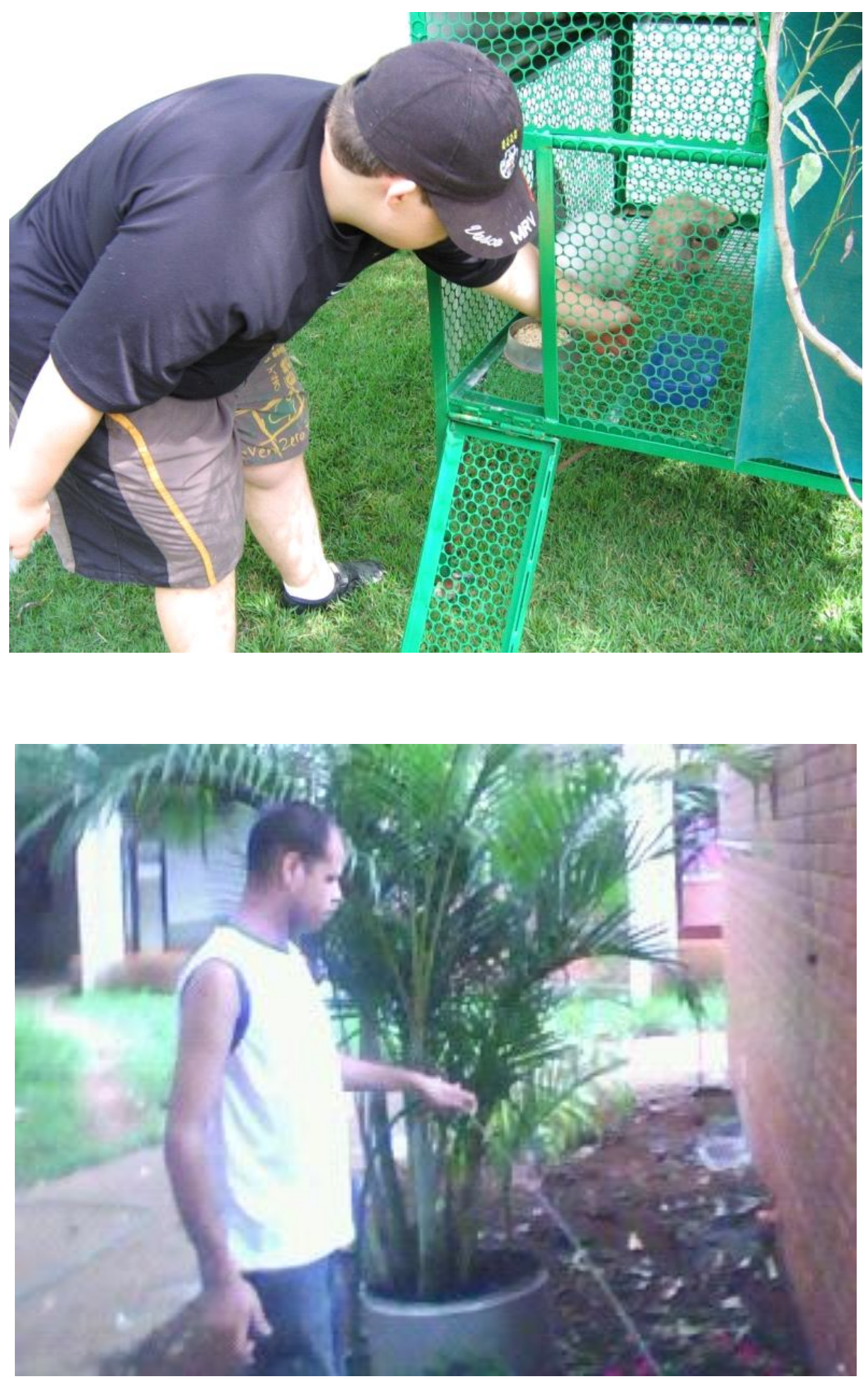


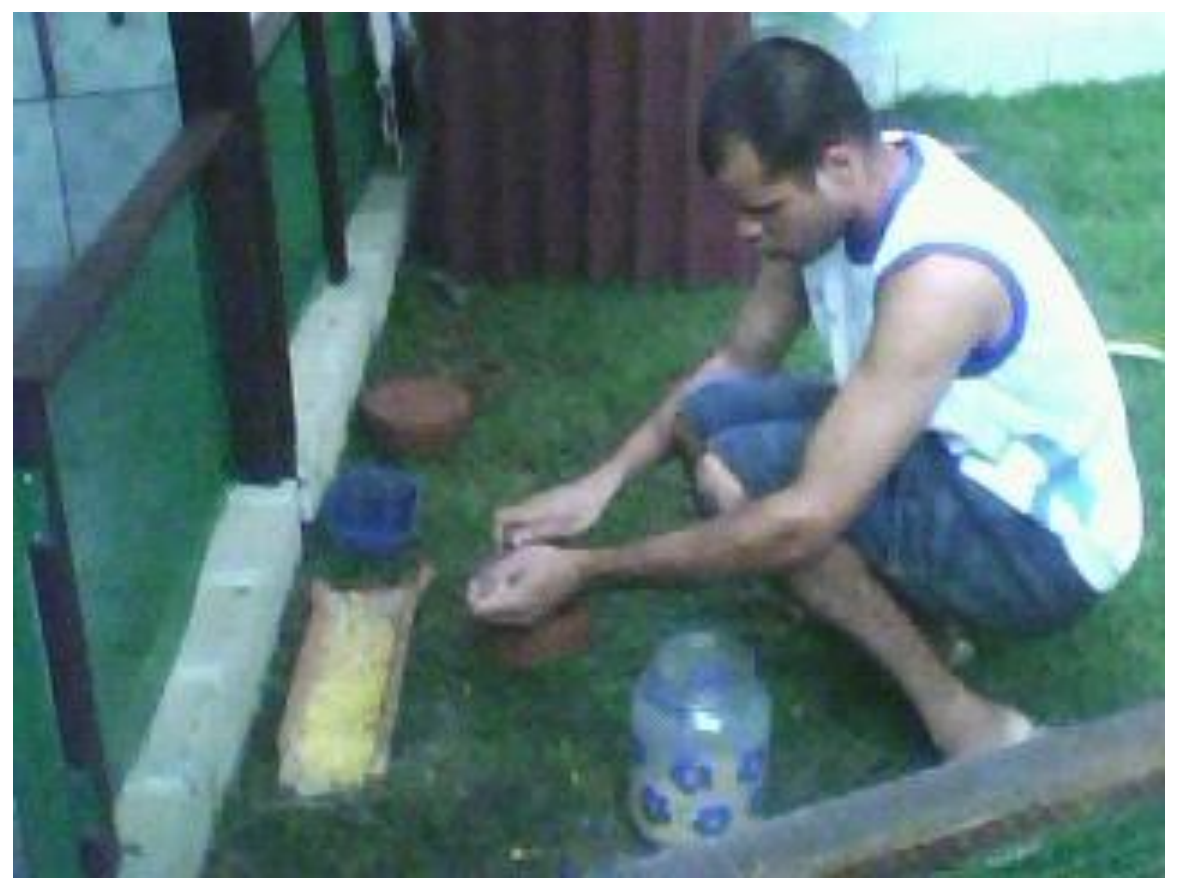

Nota da autora: Todas as fotos das pessoas mostradas neste trabalho foram autorizadas pelos responsáveis legais das mesmas. 


\section{2- OBJETIVOS}

Diante da realidade vivenciada pela autora como professora em uma escola pública de Brasília e do seu contato com alunos diagnosticados como Alunos com Necessidades Educacionais Especiais, e das melhorias observadas a partir do contato desses com animais de estimação, tornou-se clara a necessidade de se estudar as variáveis relacionadas a essas melhorias, principalmente no que diz respeito à inclusão desses alunos.

\section{1- Objetivo Geral:}

- Analisar e refletir como a Oficina Bichoterapia - Amigo Especial, contribui no processo de inclusão.

\section{2- objetivos Específicos:}

- Registrar os benefícios da interação homem e animal.

- Investigar os aspectos positivos e negativos da Oficina Bichoterapia - Amigo Especial. 


\section{3- METODOLOGIA}

\section{1- Fundamentação Teórica da Metodologia}

Tendo como objetivo uma pesquisa exploratória, ou seja, que estimule o entrevistado a pensar livremente sobre algum tema, objeto ou conceito. Optou-se pelo método qualitativo com entrevistas semi-estruturadas.

Segundo Branco e Valsiner (2004) consideram ser tarefa do pesquisador construir com uma metodologia, adequada aos objetivos do projeto, que seja suficientemente clara, precisa e sistemática e, ao mesmo tempo, flexível e capaz de adaptar-se a cada etapa do processo de investigação.

De acordo com González Rey (2002) o pesquisador ao escolher a abordagem qualitativa se deve ao fato desta pesquisa buscar entender os processos e as trocas feitas em um determinado contexto social interativo, a escola. É preciso entender que as relações e interações entre os envolvidos na busca da compreensão do ser como produto da ação histórico-cultural.

\section{2- Contexto da Pesquisa}

A pesquisa foi realizada no local de trabalho da autora. Trata-se de um Centro de Ensino Especial que atende a jovens e adultos com Necessidades Educacionais Especiais a partir dos 14 anos de idade.

O Centro Especial iniciou suas atividades em 28 de agosto de 1973. A escola possui um espaço bastante agradável: amplo, arborizado, bem dividido e se encontra muito bem localizada.

\section{- Missão}

O Centro tem como objetivo desenvolver habilidades e competências necessárias para o desenvolvimento integrado das rotinas educacionais dos 
alunos com Necessidades Educacionais Especiais, favorecendo a integração destes com metodologias que priorizem a motivação e a satisfação no ambiente escolar. Busca novos caminhos e novas abordagens que estimulem mudanças e transformem discursos em atitudes concretas.

Lembrando que devemos renovar nossos interesses, com a mesma freqüência que se renovam os dias, pois a estagnação vai contra os movimentos do mundo e da vida.Potencializando as aquisições trazidas pelos alunos, enriquecendo suas experiências através de uma prática pedagógica coparticipativa, envolvendo a comunidade escolar e respeitando as individualidades, além de representar a transição para a escola inclusiva.

\section{Atendimentos}

Em função das peculiaridades de cada um, a escola se organizou estabelecendo três modalidades de atendimento de acordo com orientações dos PCN's:

A Ofiina Bichoterapia - Amigo Especial é uma modalidade de atendimento do Centro de Ensino Especial desde fevereiro de 2009. Funciona como uma oficina motivadora, onde alguns alunos têm, dentro de sua carga horária de aula, um atendimento de $45 \mathrm{~m}$ (quarenta e cinco minutos), com a Atividade Assistida por Animais (AAA). Além dos atendimentos, a Oficina Bichoterapia - Amigo Especial realiza no Centro Especial atividades lúdicas, das quais todos os alunos do Centro participam.

Como já foi mencionado, em função das especificidades de cada aluno, a escola se organizou estabelecendo algumas modalidades de atendimento. De acordo com orientações dos PCN's, são elas: currículo funcional, currículo adaptado, oficinas de produção, oficinas motivadoras, LIEDE'S (informática) e Educação Física. Seu horário de funcionamento é maturno matutino e vespertino e atende a um total de duzentos alunos. 
Está localizado, também nesse mesmo Centro Especial, o "Centro de Atendimento ao Surdo" (CAS).

\section{- Currículo Funcional Natural}

Até o ano de 2009, o Centro de Ensino Especial trabalhava com as "Competência e Habilidades" com o 1ำ seguimento da Educação de Jovens e Adultos (EJA). A partir do ano de 2010, esse mesmo seguimento passou a ser atendido pelo "Currículo Funcional Natural": No currículo funcional Natural, segundo o Projeto Político Pedagógico do Centro, segue as seguintes propostas:

São consideradas habilidades funcionais as que ocorrem frequentemente em ambientes naturais, como em casa, na escola, no lazer, nas atividades ocupacionais e na comunidade. São desenvolvidas a partir de experiências reais e envolvem a cooperação do aluno, dos professores e da família no planejamento das atividades que favorecem uma aprendizagem significativa.

A proposta do Currículo Funcional Natural, na Educação Especial, fundamenta-se na Abordagem Ecológica, que estrutura-se no contexto comunitário participativo, culturalmente adaptado e apoiado no conhecimento do aluno, de seu meio e das relações recíprocas entre os mesmos, inseridos em contexto que engloba os valores pessoais, familiares e da comunidade a que pertencem, bem como o ambiente físico social, geográfico e histórico.

Alguns aspectos que devem ser considerados no Currículo Funcional:

- Planejamento individualizado;

- Desenvolvimento de habilidades funcionais que estejam vinculadas à qualidade de vida;

- Adequação à idade cronológica;

- Prioridade ao ambiente natural do aluno para realização das atividades; 
- Participação efetiva dos pais no processo educacional, já que são eles que melhor conhecem o aluno e podem identificar com maior precisão, quais as habilidades que necessariamente deveriam se adquiridas;

- Interação com outros alunos não-deficientes uma vez que são os colegas que proporcionam a entrada dos jovens nas experiências normais de vida em grupo de idade.

Observação: Para elaborar o Plano Pedagógico Individual - PPI, no Currículo Funcional Natural, é extremamente importante conhecer o aluno, bem como seu estilo de aprendizagem, para poder se traçar o perfil do educando, mas a participação da família é algo imprescindível, para que os objetivos propostos no planejamento escolar sejam alcançados com sucesso.

\section{3- Participantes}

Participaram das entrevistas: três alunos atendidos pela Oficina, dois professores regentes, um responsável e a vice-diretora do Centro de Ensino Especial.

\section{Alunos:}

Identificação: "A".

Diagnóstico: Deficiência Intelectual.

Data de nascimento: 19/05/1986.

"A" foi indicado para o atendimento na oficina por se encontrar insatisfeito em sala de aula. Sempre procurando uma ocupação na escola, como auxiliar os professores, ajudando-os com os colegas, ajudando a coordenadora a distribuir os avisos entre outros alunos, etc. Muitas vezes, "A" imaginava-se como um servidor da escola: porteiro, assistente, monitor, etc. 
Por esses motivos, a Oficina Bichoterapia - Amigo Especial trabalhou, principalmente, com "A" a capacitação profissional nos cuidados com os animais, com as plantas e no senso de responsabilidade e cidadania. $O$ objetivo do trabalho em relação a "A" é que ele, futuramente, possa atuar em um espaço onde haja animais, como um pet.

Identificação: "M".

Diagnóstico: Síndrome de Down.

Data de Nascimento: 10/04/1992.

Aluno com problemas comportamentais. São poucas as pessoas que conseguem uma boa relação com ele. No relatório, os professores o classificam como difícil, indisciplinado, hiperativo, agressivo e muito pouco receptivo com pessoas que não fazem parte do seu convívio diário. Por essa razão, "M" está sendo atendido pela oficina.

Por meio da interação com os animais da oficina está sendo trabalhado, em especial, o lado social e emocional de "M"

Identificação:"AR"

Diagnóstico: Deficiência intelectual, auditiva e visual.

Data de nascimento: 19/07/1967.

Atendido na oficina por apresentar problemas sociais, emocionais e, principalmente, pela "zoofobia" (medo de animais), principalmente de cães.

Por meio de uma abordagem cuidadosa, as dificuldades de "AR" são trabalhadas por meio de atividades lúdicas e prazerosas.

O objetivo principal da Oficina é tornar o aluno mais sociável. E, de acordo com a resposta do aluno, ir desfazendo o seu trauma.

\section{Professores:}

Identificação: P. 1 ( professora do aluno "A"). 
Graduação em Pedagogia.

Especialização: Neuropedagogia.

Identificação: P. 2 (professora do aluno ( "M").

Graduação: Geografia.

Especialização: Psicopedagogia.

\section{Responsável:}

Identificação: R (irmã do aluno (“AR")

Formação: Psicologia.

Ocupação: Presidente do Conselho Escolar do Centro de Ensino Especial.

\section{Vice- diretora}

Identificação: V.D.

Formação: Graduada em Educação Física

Especialização: Educação Física na Educação Especial

Tempo no cargo: três anos

\section{4 - Materiais}

Os principais materiais no estudo foram: papel, caneta, lápis, borracha. Os equipamentos: gravador, computador e impressora,

\section{5- Instrumentos de Construção de Dados}

A escolha da entrevista como método de pesquisa se deve, principalmente, aos seguintes fatores: ao contrário dos questionários, no quais se cria uma relação hierárquica entre pesquisador e informante, "na entrevista a relação que se cria é de interação, havendo uma atmosfera de influência recíproca entre quem pergunta e quem responde" (Lüdke e André, 1986, p.33). Além disso, "a entrevista permite a captação imediata e corrente da informação desejada" (ibidem) e há mais espaço para correções, esclarecimentos e aprofundamentos de certas questões. 
Para Lakatos e Marconi(1994, p.195), a entrevista deve ser entendida como "um encontro entre duas pessoas, a fim de que uma delas obtenha informações a respeito de um determinado assunto, mediante uma conversação de natureza profissional'.

Foram utilizados roteiros de entrevistas (em anexo). Porém, o entrevistador é livre para adaptá-las, de acordo com a situação, bem como o entrevistado é livre para responder, podendo, inclusive, fugir do roteiro.

\section{6- Procedimentos de Construção de Dados}

Por se tratar de um estudo sobre uma prática desenvolvida pela autora, os procedimentos ocorreram de uma forma relativamente natural e sem dificuldades. Inicialmente foi apresentado o projeto de pesquisa para a equipe gestora. Em seguida, foram planejadas as medidas a serem adotadas em seguida: autorizações para as entrevistas, escolha dos entrevistados, horários para as entrevistas, entre outros.

Inicialmente, pensou-se em entrevistar três pessoas de cada grupo, mas devido à disponibilidade de alguns participantes esse numero foi reduzido. A soma total das entrevistas foi: dois professores, três alunos, um responsável e um participante da equipe gestora.

O critério da escolha dos alunos para participar da pesquisa foi, além de os mesmos possuírem linguagem verbal, apresentarem comportamentos e necessidades diferentes, na verdade distintos ou extremos. Já para os professores, foram escolhidos por serem regentes de alunos atendidos na oficina. No caso da pessoa responsável, além de ser irmã de um aluno da oficina, possuía um cargo no Conselho Escolar (presidente). A vice-diretora foi escolhida por estar diretamente ligada às questões pedagógicas do Centro. 


\section{7- Procedimentos de Análise de Dados}

Por se tratar de uma pesquisa qualitativa, optou-se pela definição de categorias. Como o objetivo do estudo é analisar a contribuição da Oficina Bichoterapia no processo de inclusão foram desenvolvidas as seguintes categorias: 01- Contribuições da Bichoterapia observadas em relação a inclusão: 02- Relação (resposta, satisfação) dos alunos com a Oficina Bichoterapia - Amigo Especial. Essas categorias foram formadas de acordo com as observações e respostas das entrevistas adquiridas junto aos participantes da pesquisa. 


\section{4- RESULTADOS E DISCUSSÃO}

Esse capítulo tem como objetivo analisar as informações advindas das observações e entrevistas realizadas durante a pesquisa. Para melhor compreensão dos resultados, como já foi mencionado, as questões foram divididas em categorias, que surgiram a partir das respostas dos entrevistados. Em seguida, foi realizada a análise dos dados de acordo com as observações feitas durante o estudo, as respostas obtidas durante as entrevistas e as fundamentações teóricas contidas no trabalho.

Segue abaixo quadros com a síntese das respostas dos entrevistados da:

\section{Categoria 01:}

\section{QUADRO A}

\section{Entrevistado P.1:}

Contribuição Observadas na Oficina Bichoterapia-Amigo Especial, em relação a Inclusão:

\begin{tabular}{|c|c|}
\hline $\begin{array}{l}\text { Oficina Bichoterapia- amigo Especial } \\
\text { áreas: }\end{array}$ & Contribuições observadas: \\
\hline SOCIAL & Ajuda na interação, aumento da sociabilidade. \\
\hline EMOCIONAL & Desenvolvimento da iniciativa. \\
\hline COGNITIVA & $\begin{array}{l}\text { Ajuda a aumentar a atenção, melhora a coordenação } \\
\text { motora, a linguagem, desenvolve as atividades da vida } \\
\text { diária }\end{array}$ \\
\hline FÍSICA & Estimula atividades saudáveis \\
\hline
\end{tabular}




\begin{tabular}{|l|l|}
\hline ECOLÓGICA & Zelo e cuidado com a natureza e os animais \\
\hline CAPACITAÇÃO PROFISSIONAL & Cuidar dos animais, senso de responsabilidade. \\
\hline & \\
\hline
\end{tabular}

Análise:

Observa-se, a partir o Quadro A, que a professora P1 mostra-se favorável ao trabalho desenvolvido pela oficina. De acordo com suas respostas, não somente o seu aluno, mas também outros atendidos pela oficina, estão tendo uma resposta bastante positiva. "O meu trabalho, e o trabalho de uma colega mais próxima aqui da escola, melhorou muito depois que a oficina começou aqui no Centro e os nossos meninos estão mais ativos" (professora1). O que ajuda, segundo a mesma, no processo inclusivo.

Percebe-se que, segundo ainda o quadro $A$, na opinião de $P 1$, todas as áreas são trabalhadas na oficina, favorecendo a inclusão do aluno na sociedade.

\section{QUADRO B}

Entrevistado-P2:

\begin{tabular}{|l|l|}
\hline $\begin{array}{l}\text { Oficina Bichoterapia- amigo Especial } \\
\text { áreas: }\end{array}$ & \multicolumn{1}{|c|}{ Contribuições observadas: } \\
\hline SOCIAL & $\begin{array}{l}\text { Ajuda nos relacionamentos.Melhora do comportamento } \\
\text { controla a hiperatividade, desenvolve a maturidade. }\end{array}$ \\
\hline EMOCIONAL & $\begin{array}{l}\text { Complemento para as atividades pedagógicas } \\
\text { Desenvolve o cognitivo. }\end{array}$ \\
\hline COGNITIVA & Ajuda na locomoção \\
\hline FíSICA & Amor aos animais \\
\hline ECOLÓGICA & \\
\hline CAPACITAÇÃO PROFISSIONAL & \\
\hline &
\end{tabular}


Análise:

A entrevistada P2, como podemos observar no quadro $B$, deu ênfase as áreas emocional e cognitiva, trabalhadas na oficina.

Por se tratar da professora regente do aluno M, a entrevistada acredita que a interação do aluno com os animais da oficina o tornou mais disciplinado, ajudaram na melhoria de sua hiperatividade e no seu relacionamento com os colegas e demais e professores.

"Fica mais fácil lidar com as crianças, pois elas estão mais calmas e não brigam tanto dentro de sala de aula. Acho que é porque agora elas têm no bichinho uma maneira de fazer carinho, e receber carinho do bichinho também".

“...Animais de companhia também se mostraram bastante prestativos para crianças tanto em casa quanto na escola. Eles aumentam a auto-estima da criança, melhoram sua integração na sala de aula, incentivam o contato social com outras crianças e aumentam sua vontade de aprender. Há, ainda, casos bem-sucedidos de animais como auxiliares interagindo com doentes psíquicos que não se comunicam; crianças hiperativas ou agressivas; portadores de síndrome de Down; pacientes com mal de Alzheimer; pacientes com problemas neurológicos e deficientes físicos. (Turner $^{5}$, 2001) 


\section{QUADRO C}

Entrevistado R:

\begin{tabular}{|l|l|}
\hline $\begin{array}{l}\text { Oficina Bichoterapia- amigo Especial } \\
\text { áreas: }\end{array}$ & \multicolumn{1}{|c|}{ Contribuições observadas: } \\
\hline SOCIAL & $\begin{array}{l}\text { Sociabilidade } \\
\text { Empoderamento, aumento da autoestima, superação } \\
\text { do medo e motivação. }\end{array}$ \\
\hline COGNITIVA & $\begin{array}{l}\text { Ampliação do conhecimento e correlação com outros } \\
\text { conteúdos pedagógicos. }\end{array}$ \\
\hline FÍSICA & Ajuda na locomoção \\
\hline ECOLÓGICA & Interação com os animais domésticos, \\
\hline CAPACITAÇÃO PROFISSIONAL & \\
\hline & \\
\hline
\end{tabular}

Análise

O quadro $C$ nos mostra que a entrevistada $R$ acredita que a Oficina em questão está realizando um trabalho bastante positivo no que diz respeito às contribuições para a inclusão.

Por se tratar, como já mencionado, de uma pessoa bastante participativa no Centro Especial, além de ser uma profissional com conhecimento na área, $R$ demonstrou bastante segurança, conhecimento e fundamentações nas suas respostas, enfatizando sempre a importância de uma educação que vá além dos limites da sala de aula, o que remete às "aulas passeios" de Célestin Freinet: " 0 interesse das crianças estava lá fora, assim era preciso colocá-las em contato com a natureza e com os mundos social e cultural, levando-as para onde se sentiam felizes: lá fora" (SAMPAIO, 1989, p. 15) (...) A força da natureza sensibilizava cada 
uma das crianças de acordo com sua personalidade, sua percepção de mundo e sua curiosidade. (...) Era a vida entrando na sala de aula". (SAMPAIO, 1989, p. 1516)

\section{QUADRO D}

\section{Entrevistado VD:}

\begin{tabular}{|c|c|}
\hline $\begin{array}{l}\text { Oficina Bichoterapia- amigo Especial } \\
\text { áreas: }\end{array}$ & Contribuições observadas: \\
\hline SOCIAL & Desenvolve a maturidade, aumenta a afetividade \\
\hline EMOCIONAL & Noções de limites, aumento da autoestima , \\
\hline COGNITIVA & Desenvolve a concentração, prática pedagógica eficaz. \\
\hline FÍSICA & Ajuda na locomoção \\
\hline ECOLÓGICA & Interação com os animais domésticos \\
\hline CAPACITAÇÃO PROFISSIONAL & $\begin{array}{l}\text { Senso de responsabilidade. Cuidados com os animais } \\
\text { domésticos }\end{array}$ \\
\hline
\end{tabular}

Análise

Conforme podemos constatar no quadro acima, o entrevistado apontou contribuições em todas as áreas da oficina. Outro ponto importante da fala de VD é quanto aos pontos negativos e às sugestões a respeito da Oficina: "Falta funcionário qualificado para cuidar do ambiente durante a semana, nos finais de semana, feriados e férias escolares. Tudo fica por conta do professor. Ambiente mais adequado, sala mais ampla, limpeza do espaço mais eficiente, mais bichos, mais professores atuando para atender um número maior de alunos, parceria para cuidado dos animais e compra de alimento., Ffuncionário qualificado para cuidar do 
ambiente". Percebe-se, pela fala de VC, que os defeitos da oficina não está na parte pedagógica e sim na estrutura física e administrativa. Observação bastante interessante, visto que VC é um dos membros da equipe gestora do Centro Especial.

De acordo com a análise feita por VD, A Oficina Bichoterapia-Amigo Especial, vem desenvolvendo um ensino de qualidade.

Para a $2^{\mathrm{a}}$ categoria, segue entrevistas transcritas, seguida pela análise:

\section{Relação dos Alunos em Relação à Oficina Bichoterapia - Amigo Especial}

\section{Aluno "A"}

Entrevistador - O que você gosta, e o que você não gosta na Bichoterapia?

A- Sim

Entrevistador - O que é chato na Bichoterapia: limpar o galinheiro, o lugar dos coelhinhos, dar comida? O que é mais chato aqui?

A - Eu gosto de tudo.

Entrevistador - O que é que você mais gosta da Oficina Bichoterapia?

A - Limpar a sala.

Entrevistador - E mais o que?

A - Colocar ração, milho, limpar ali (apontou para a o local onde fica o casal de coelhos), molhar a planta. É o que eu te falei.

Entrevistador - O que é que você gostaria que tivesse aqui no Bichoterapia?

A- Galinha.

Entrevistador - Mas galinha já tem. O que é que não tem e que você queria que tivesse aqui no Bichoterapia?

A - Ração, milho... 
Entrevistador - Não A, mas isso tudo já tem. O que é que não tem aqui e você queria que tivesse?

A. - (Não soube responder).

Entrevistador - Você gostaria de trabalhar aqui, na escola, em alguma coisa?

A- limpar as coisas, dar ração, passear com "SIG" (nome do cachorro da Oficina).

Entrevistador - Mas você gostaria de trabalhar em mais o que, além de dos bichinhos?

A - ajudar a "chefe" (a coordenadora na secretaria), lavar o carro, porteiro.

Entrevistador - O que você gostaria também de aprender a fazer, a trabalhar?

A - Dar remédio aos bichos.

Por meio da fala do aluno, percebe-se a sua necessidade de ser produtivo, útil e, ao seu modo de ver, importante. Demonstrando sempre preferência por tarefas participativas, significativas, que o levem a aprender alguma profissão. Percebe-se nele, a alegria e satisfação em realizar as atividades propostas, desenvolvendo-as sempre com eficácia, responsabilidade e, principalmente, prazer. Atividades essas que estão de acordo com o Currículo Funcional Natural, que se encontra no Projeto Político Pedagógico da Escola. Como se pode verificar a seguir:

\footnotetext{
"São consideradas habilidades funcionais as que ocorrem frequentemente em ambientes naturais, como em casa, na escola, no lazer, nas atividades ocupacionais e na comunidade. São desenvolvidas a partir de experiências reais e envolvem a cooperação do aluno, dos professores e da família no planejamento das atividades que favorecem uma aprendizagem significativa".
}

\section{Aluno “M":}

Entrevistador O que você não gosta, é chato no Bichoterapia?

M - Eu gosto. 
Entrevistador - Mas do que é que você menos gosta?

M - Carlos é chato ( um aluno do Centro)

Entrevistador - E aqui, na Bichoterapia, tem alguém ou algum bichinho que você acha chato?

$\mathrm{M}-\mathrm{Amo}$

Entrevistador - Você gosta de ficar aqui no Bichoterapia?

M- Gosta

Entrevistador - Do que você mais gosta aqui no Bichoterapia?

M - Galo e galinha e o milho da galinha, e é maravilhoso o galinheiro, aqui !

Entrevistador - O que é que você queria que tivesse aqui no Bichoterapia?

M - Vou cantar menino da porteira.

Entrevistador - Tem alguma coisa: brincadeira, bichinho, que não tem aqui que você queria que tivesse?

Entrevistador - Ficar sozinho.

Entrevistador - Você Gostaria de trabalhar em alguma coisa aqui na escola?

M- Com os bichinhos

Entrevistador - Em outro lugar, não aqui no Bichoterapia?

- M - Jogador de Futebol

Entrevistador - E aqui na escola, sem ser no Bichoterapia, você queria fazer o que: pintar, tocar música, lavar carro.

M- tocar música, Daniel ( cantor sertanejo) 
Como já foi mencionado, as principais dificuldades de $\mathrm{M}$ são sociais e emocionais. Dificuldades essas que são imperceptíveis durante os atendimentos. O aluno $\mathrm{M}$, como se pode observar na sua fala, demonstra muita satisfação durante as aulas demonstando um carinho especial pelas aves.

O aluno realiza as atividades sem maiores problemas. E, o que mais importante, está apresentando importantes conquista, Como já contatado acima, pela professora regente do aluno ( P2). Como disse De Carlo (2006):

Em geral, quando matriculamos uma criança com Síndrome de Down na escola, esperamos com base nas prescrições médicas, que o seu desenvolvimento intelectual apresente perdas em função de aspectos marcados pelas determinações genotípicas. Contudo, algumas pesquisas revelam que essa forma de se posicionar é equivocada, pois o diagnóstico possui limitações e os sujeitos, muitas vezes, rompem com as expectativas esperadas, apresentando um desenvolvimento mental muito mais avançado do que aquelas indicadas nas avaliações quantitativas.

E são nesses preceitos que a Oficina - Bichoterapia Amigo Especial trabalha com seus alunos. E, como nos mostra "M", vem conseguindo alcançar bons resultados.

\section{Aluno "AR"}

Entrevistador - O que você não gosta, acha chato no Bichoterapia?

AR - Gosto.

Entrevistador -- O que é que você mais gosta do Bichoterapia?

AR - De bichinho.

Entrevistador - De qual é o bicho que você mais gosta?

AR- "Sig" (o cachorro Sigmund Freud) 
Entrevistador - O que é que você quer que tenha aqui no Bichoterapia? Alguma coisa, bicho, jogos, brincadeiras, uma coisa que ainda não tem aqui, no Bichoterapia?

- Rádio, música baixinho (segundo a professora de sala de aula, apesar da pouca audição, ele gosta de realizar as atividades ouvindo música).

Entrevistador - Você gosta de fazer, trabalhar em o que?

AR - Nada

Entrevistador - Nada, não gosta de pintar, fazer comida, dançar, cuidar dos bichinhos?

AR- É

Entrevistador - Então, o que você gosta de fazer?

AR - Passear com "SIG" (cachorro da oficina), comer, te amo.

$A R$ foi um dos casos onde a resposta foi mais rápida. Atendido na Oficina, por apresentar problemas sociais, emocionais e, principalmente, pelo pânico que tinha quando ficava perto de animais. Logo no primeiro atendimento, AR demonstrou simpatia, não somente pelo cachorro, mas por todos os animais da oficina $E$, depois de poucos atendimentos, suas dificuldades sociais e emocionais já não eram tantas, comparando-se a fala de AR com a fala da sua irmã $R$, podese constatar os grandes avanços que o aluno conquistou.

Fazendo uma análise sintética desses três casos, foi possível constatar que a interação do homem com os animais domésticos desempenhou um papel fundamental para que fosse possível alcançar muitos dos objetivos propostos. No caso do aluno "A", ao cuidar dos animais, o mesmo se sentiu útil, responsável e importante; já no caso do aluno "M", ao "desabafar com o amigo Zé" the foi possível atingir um nível de felicidade e tranqüilidade de que necessitava naqueles 
momentos, desenvolvendo suas atividades de maneira serena; e no de "AR", que devido a uma abordagem mais acertada, com os "amigos especiais“, conseguiu se livrar der um trauma que Ihe havia gerado alguns problemas.

"Todo esse processo de busca e descobertas nos desvela o processo educativo, 'a educação como um ato de conhecimento', que nunca se esgota, que é permanente e vital" (FREIRE, 2002, p. 54). 


\section{5- CONSIDERAÇÕES FINAIS}

O trabalho aqui apresentado teve como objetivo estudar algumas abordagens pedagógicas que utilizam animais domésticos como coadjuvante, bem como apresentar as contribuições da Oficina Bichoterapa - Amigo Especial na inclusão de Alunos com Necessidades Educacionais Especiais, no CE onde a autora trabalha, e de que maneira essa prática educacional vem acontecendo, no Centro de Ensino Especial, onde a autora trabalha.

Diante dos resultados analisados, foi possível constatar que a Oficina Bichoterapia - Amigo Especial, está conseguindo alcançar os seus objetivos, ou seja, apresentar um prática educacional atualizada, dinâmica e significativa, que está de acordo com a realidade e a necessidade do aluno com Necessidade Educacional Especial, contribuindo, assim, para o processo de inclusão.

Podem se destacar, segundo alguns participantes da pesquisa, como contribuições dessa prática educacional o aumento da auto-estima, 0 desenvolvimento da coordenação motora, a estimulação da linguagem oral, a estimulação da socialização, o aumento da capacitação profissional, entre outras.

Há um longo caminho a ser percorrido para que se consiga, de fato, se não cem por cento dos alunos, pelos menos o maior número possível desses alunos especiais em programas de inclusão escolar. Autores tidos com autoridades em educação são quase unânimes em afirmar que todos os alunos têm potenciais, ainda que não visíveis a olho nu, mas que merecem a oportunidade de fazerem parte da jornada rumo ao conhecimento, socialização e realização ampla de sua potencialidades.

Porém, é importante ressaltar que não se deve descuidar daqueles que, por inúmeros motivos, ainda permanecem em Centros de Ensino Especiais. Por isso mesmo, torna-se imprescindível a busca por alternativas educacionais mais criativas, úteis e prazerosas para esses alunos, fazendo assim, dos professores de Centro de Ensino Especial, contribuíntes ao processo de inclusão. 
Percalços acontecem e com certeza irão sempre acontecer. Mas nunca se deve desistir daquilo em que se acredita. A autora faz isso por todos, pelo que acredita e, principalmente, pelos alunos especiais, que podem ensinar, melhor do que ninguém, como transpor as barreiras diárias. 


\section{REFERÊNCIAS}

Becker, Marty - O Poder Curativo dos Bichos. Rio de Janeiro: Bertrand Brasil, 2003.

BRASIL. Declaração de Salamanca e linha de ação: sobre necessidades educativas especiais. Brasília, D.F: MEC, 1994.

CARNEIRO, Moacir Alves. LDB fácil: leitura crítico-compreensiva, artigo a artigo. Rio de Janeiro: Vozes, 1998.

COLE, M.; COLE, S. O desenvolvimento da criança e do adolescente. Porto Alegre: Artmed, 2003.

DE CARLO, Marysia do Prado. Se essa casa fosse nossa: instituições e processos de imaginação na Educação especial. São Paulo: Plexus, 1999.

FREIRE, Madalena. A Paixão de Conhecer o Mundo. São Paulo: Paz e Terra, 2002.

GONZÁleZ REY, Fernando Luiz. Pesquisa qualitativa em psicologia: caminhos edesafios. Tradução de Marcel Aristides Ferrada Silva. SãoPaulo: Pioneira Thomson Learning , 2002.

LÜDKE, M.; ANDRÉ, M. E. D. A. Pesquisa em educação: abordagens qualitativas. Coleção: Temas básicos de educação e ensino. São Paulo: EPU, 1986.

LURIA, A. R.;LEONTIEV, A. VYGOTSKY, L. S. Bases psicológicas da aprendizagem e do desenvolvimento. São Paulo: Moraes, 1991.

MANTOAN, Maria Teresa Eglér. Educação de qualidade para todos: formando professores para inclusão escolar. Temas sobre Desenvolvimento, São

Paulo, v. 7, n.40.

PÁDUA, Gelson Luiz Daldegan de. Revista FACEVV | 1옹 Semestre de 2009 | Número 2 | p. 22-35.

PRENDIMI L'Anima. Direção de Roberto Faenza. Itália/França/Reino Unido, Paris Filmes, 2003.

SASSAKI, Romeu Kazumi. Inclusão: construindo uma sociedade para todos. 30ª ed. Rio de Janeiro: WVA, 1999.

SILVEIRA, Nise da. O Mundo das Imagens. São Paulo, SP: Ática S.A, 1992. 
SILVEIRA, Nise da. Gatos, A Emoção de Lidar .Rio de Janeiro : Léo Christiano 1998.

SOARES, Marlene da Silva; CARMONA, Olímpio Ordonez. Fundamentos da Educação Especial. Módulo III, Volume 3 - Eixo Integrador: Educação e Trabalho. Áreas/Dimensões Formadoras: Organização do Processo Educativo e Organização do Processo Social. Curso de Pedagogia para Professores em Exercício no Início de Escolarização - PIE, 2002.

VACCARI, Andreia Maria Heins; Almeida, Fabiane de Amorim. A importância da visita de animais de estimação na recuperação de crianças hospitalizadas. Trabalho de conclusão de curso apresentado à Faculdade de Enfermagem do Hospital Israelita Albert Einstein, São Paulo (SP), Brasil. Disponível em: http://apps.einstein.br/REVISTA/arquivos/PDF/419-Einstein5-

2 Online AO419 pg111-116.pdf

VYGOTSKy, L.S. Fundamentos de defectologia. La Habana: Pueblo y

Educacíon, 1995. tomo 5.

VYGOTSKY, Lev S. O desenvolvimento psicológico na Infância. São Paulo: Martins Fontes, 1998.

VYGOTSKY, Lev S. A construção do pensamento e da linguagem. São Paulo: Martins Fontes, 2000.

WERNER, J. Saúde e Educação: desenvolvimento e aprendizagem do aluno. Rio de Janeiro: Gryphus, 2000.

ZACHARIAS, Vera L.C. Montessori. Centro de Referência Educacional. Junho de 2005. Disponível em: <www.centrorefeducacional.com.br>. Acesso em: 11/06/2007. 


\section{ANEXO I \\ - ENTREVISTAS -}

\section{Entrevista com R:}

P- Antes daOficina Bichoterapia Amigo - Especial, você já conhecia algum tipo de atendimento que utilizasse animais de estimação?

R: Dentro da escola não.

P- Qual foi sua primeira opinião a respeito dessa Oficina? Continua a mesma?

R: Favorável. Sim, continuo com a mesma opinião, os resultados que os alunos apresentam são importantes.

P- Você conhece alguém que esteja sendo, ou já foi atendido pela Oficina Bichoterapia - Amigo Especial? Quem?

R: Sim, meu irmão.

P- Há quanto tempo essa pessoa é atendida pela Oficina?

R: Três anos.

P- Quais os principais motivos que levaram essa pessoa a ser atendido pela Oficina?

R: Dificuldade de relacionamento com animais e a diversificação pedagógica.

P- A Oficina trouxe, ou está trazendo, algum benefício para essa pessoa. Se afirmativa, quais?

R: Sim. Social: em ambientes onde tenha animais o comportamento dele já é adequado. Emocional: (...)empoderamento, auto-estima positiva, superação do medo e motivação. Pedagógico: ampliação de conhecimentos e correlação com outros conteúdos pedagógicos.

P- O que você acha dos atendimentos das oficinas pedagógicas? E em particular, da Oficina Bichoterapia - Amigo Especial?

R: As oficinas pedagógicas contribuem para resignificar a educação especial oferecida ao aluno. A oficina do bichoterapia traz mais contribuição quando utiliza todo o ambiente escolar, não apenas a sala de aula, quando a partir da interação aluno-animal-professor se reforça conhecimentos como iniciação ao letramento, 
às concepções matemáticas mais básicas como contar as patas/os olhos/etc, a diferenciação entre os animais como bico/boca, o aluno com deficiência visual tem nesta oficina um vasto leque de possibilidades para ampliar seus conhecimentos.

P- Em sua opinião, você acredita que a Oficina Bichoterapia - Amigo Especial está contribuindo de alguma forma para a inclusão dos alunos com necessidades educacionais especiais para a inclusão? Cite um exemplo.

$\mathrm{R}$ : Sim. $\mathrm{Na}$ inclusão educacional amplia conhecimentos. $\mathrm{Na}$ inclusão social adequa o comportamento (em um ambiente onde apareça o animal a pessoa reage com tranquilidade).

P- Quais os pontos negativos da Oficina Bichoterapia - Amigo Especial?

R: Um atendimento/semana

P- Você teria alguma sugestão para melhorar os atendimentos da Oficina Bichoterapia - Amigo Especial?

R: Sim, três atendimentos/semana (um deles poderia ser em sala de aula com a professora regente ou até nas aulas de atividade física). Aula fora da escola sistematicamente de dois em dois meses. A experiência na água é muito rica. $O$ mundo aquático é desconhecido para alguns alunos. Assim como o ambiente aéreo. Peixes, répteis, aves assim como os mamíferos.

P- Você acha que a Oficina deva fazer parte do PPP do Centro em 2012?

R: Com certeza! Os alunos especiais adultos se beneficiarão da contribuição desta oficina em seu PPP e a comunidade escolar apoiará as propostas que

venham ao encontro das melhorias educacionais.

Arabella Pereira Nóbrega - Psicóloga e Educadora.

\section{Entrevista com P1:}

P- Antes daOficina Bichoterapia Amigo - Especial, você já conhecia algum tipo de atendimento que utilizasse animais de estimação?

R: Não, de fato foi a primeira vez que vi este tipo de trabalho, Nunca tinha visto algum tipo de terapia com animais. 
P- Qual foi sua primeira opinião a respeito dessa Oficina? Continua a mesma?

R: No primeiro momento achei que seria um trabalho de banho e tosa, mas depois fui percebendo algo mais sutil, a necessidade de interagir do aluno, vi isto acontecer, inclusive com aluno autista. Realmente foi demais.

P- Você conhece alguém que esteja sendo, ou já foi atendido pela Oficina Bichoterapia - Amigo Especial? Quem?

R: Conheço meu aluno e outros alunos da escola.

P- Há quanto tempo essa pessoa é atendida pela Oficina?

R: O meu aluno é atendido desde o ano passado, 2010, conheço outros alunos que está há mais tempo.

P- Quais os principais motivos que levaram essa pessoa a ser atendido pela Oficina?

R: No caso do meu aluno, ele é hiperativo (toma medicamento para controlar o déficit de atenção e a inquietude) também não é de expressar muito carinho..

P- A Oficina trouxe, ou está trazendo, algum benefício para essa pessoa. Se afirmativa, quais?

R: Meu aluno passou a expressar mais carinho, antes ele quase não demonstrava carinho para as pessoas, foi motivo de muita alegria, porque o carinho é forma de interagir com os outros.

P- O que você acha dos atendimentos das oficinas pedagógicas? E em particular, da Oficina Bichoterapia - Amigo Especial?

R: Gosto de todas as oficinas da escola, cada uma tem sua área de atuação específica e rica em contribuição, a oficina Bichoterapia realmente contribui muito para o aluno com dificuldades de interagir com os colegas de escola e os professores, também para aqueles de precisam desenvolver a iniciativa, o zelo e cuidado com a natureza e os animais, pois trabalha com o aluno incentivando-o a colocar alimento para as galinhas, os coelhos, o cachorro.

Quando o aluno chega à sala já vai direto para os pratinhos de alimentos dos bichos para ver como está a comida e a água.

P- Em sua opinião, você acredita que a Oficina Bichoterapia - Amigo Especial está contribuindo de alguma forma para a inclusão dos alunos com necessidades educacionais especiais para a inclusão? Cite um exemplo. 
R: A palavra "inclusão" significa preparar a escola para as necessidades específicas de cada aluno, seja qual for a sua deficiência, cada aluno tem suas limitações, uns não conseguem interagir, outros precisam ser estimulados para a autonomia e iniciativa, outros para cuidados com sua própria vida e dos outros, no caso desta oficina, a vejo trabalhando tudo isto no seu dia a dia

P- Quais os pontos negativos da Oficina Bichoterapia - Amigo Especial?

R: Não vejo nada negativo, apenas virtudes acho até que deveria ser criado mais espaço para outros animais dentro da oficina.

P- Você teria alguma sugestão para melhorar os atendimentos da Oficina Bichoterapia - Amigo Especial?

R: A minha sugestão seria ampliar a oficina para mais espaço e atrações dentro do seu projeto.

P- Você acha que a Oficina deva fazer parte do PPP do Centro em 2012?

R: Claro, com certeza, espero que isto aconteça. Outro dia veio um aluno do meu módulo, o aluno Israel pedindo para que eu arranjasse uma vaga para ele trabalhar no projeto, então respondi que não dependia de mim, ele precisa ver a resposta das coordenadoras da escola.

\section{DADOS:}

Atua no Centro de Ensino Especial - CEE 01 de Brasília há 10 anos

Graduada em Pedagogia

Pós graduada em Neuropedagogia

Trabalha com alunos portadores de deficiência múltipla e surdez.

\section{Entrevista com P2:}

P- Antes daOficina Bichoterapia Amigo - Especial, você já conhecia algum tipo de atendimento que utilizasse animais de estimação?

R: Não, vim ter conhecimento de terapia assistida aqui no CEE 01 de Brasília.

P- Qual foi sua primeira opinião a respeito dessa Oficina? Continua a mesma? 
R: A princípio achei interessante e envolvente, continua a mesma opinião ou mais pois, os resultados obtidos no decorrer do processo são interessantes.

P- Você conhece alguém que esteja sendo, ou já foi atendido pela Oficina Bichoterapia - Amigo Especial? Quem?

R: Sim, conheço vários alunos mas o que eu acho interessante é o Marcelo.

P- Há quanto tempo essa pessoa é atendida pela Oficina?

R: Aproximadamente uns três anos e a terapia é motivação para o aluno permanecer ativo no ambiente escolar.

P- Quais os principais motivos que levaram essa pessoa a ser atendido pela Oficina?

R: Ele era inquieto, hiperativo, ansioso, sem limites.

P- A Oficina trouxe, ou está trazendo algum benefício para essa pessoa. Se afirmativa, quais?

R: Ele é portador da síndrome de down e a terapia ajuda a controlar a ansiedade, estresse, locomoção entre outros fatores do cotidiano do aluno.

P- O que você acha dos atendimentos das oficinas pedagógicas e, em particular da Oficina Bichoterapia- Amigo Especial?

R: Acho interessante por ser complemento para a sala de aula.

P- Em sua opinião, você acredita que a Oficina Bichoterapia- Amigo Especial está contribuindo de alguma forma para a inclusão dos alunos com necessidades educacionais especiais para a inclusão? Cite um exemplo.

R:Com certeza! Os estímulos nos alunos levam (...)eles à maturidade, quero dizer controle da hiperatividade, ansiedade, entre outros deixando prontos para um bom desenvolvimento cognitivo ou quem sabe a incluão.

P- Quais os pontos negativos da Oficina Bichoterapia - Amigo Especial?

R: Atualmente não vejo pontos negativos para os beneficiados que são principalmente os alunos porem para quem desenvolve o projeto acaba se tornando complicado por falta de recursos e apoio financeiro da SEDF.

P- Você teria alguma sugestão para melhorar os atendimentos da Oficina Bichoterapia- Amigo Especial? 
R: O projeto está excelente, ficaria melhor se fosse ampliado com 2 professores por turno para aumentar o número de atendimentos e dar assistência a escolas classes com os alunos da sala de apoio.

P- Você acha que a Oficina deva fazer parte do PPP do Centro em 2012?

$\mathrm{R}$ : O projeto só tem a crescer e hoje o centro precisa continuar esse trabalho, os alunos só tem ganhos.

\section{Entrevistada com VD:}

P- Antes da Oficina Bichoterapia Amigo - Especial, você já conhecia algum tipo de atendimento que utilizasse animais de estimação?

R: sim, animais terapeutas que trabalham com idosos e doentes.

P- Qual foi sua primeira opinião a respeito dessa Oficina? Continua a mesma?

R: achei que seria bom para os alunos por saber da experiência positiva realizada no centro do Guará. A oficina é uma experiência positiva para a escola.

P- Você conhece alguém que esteja sendo, ou já foi atendido pela Oficina Bichoterapia - Amigo Especial? Quem?

R:Alguns alunos da escola foram selecionados $p$ participarem da oficina.

P- Há quanto tempo essa pessoa é atendida pela Oficina?

R: A Oficina funciona há três anos na escola. Alguns alunos estão desde o início, outros iniciaram esse ano.

Quais os principais motivos que levaram essa pessoa a ser atendido pela Oficina? $\mathrm{R}$ : Os pré-requisitos são exigidos pela oficina e os alunos avaliados pela professora.

P- A Oficina trouxe, ou está trazendo algum benefício para essa pessoa. Se afirmativa, quais?

R: Sim, notoriamente os alunos aprendem a lidar melhor com os animais, relaxar, lidar com limites e responsabilidades.

P- O que você acha dos atendimentos das oficinas pedagógicas? E em particular da Oficina Bichoterapia- Amigo Especial? 
R: As oficinas são importantes para desenvolverem atitudes mais maduras nos alunos. A bichoterapia é importante para os alunos com deficiência intelectual mais acentuada, pois desenvolve aspectos de autoestima, concentração, controle emocional e afetivo.

P- Em sua opinião, você acredita que a Oficina Bichoterapia- Amigo Especial, está contribuindo de alguma forma para a inclusão dos alunos com Necessidades Educacionais Especiais para inclusão? Cite exemplos.

R: A partir do momento que estimula e promove a mudança de comportamento.

P- Quais os pontos negativos da Oficina Bichoterapia - Amigo Especial?

R: Falta funcionário qualificado para cuidar do ambiente durante a semana, nos finais de semana, feriados e férias escolares. Tudo fica por conta do professor.

Você teria alguma sugestão para melhorar os atendimentos da Oficina Bichoterapia- Amigo Especial?

$\mathrm{R}$ - Ambiente mais adequado, sala mais ampla, limpeza do espaço mais eficiente, mais bichos, mais professores atuando para atenderem um número maior de alunos, parceria $p$ cuidado dos animais e compra de alimentos, funcionário qualificado $p$ cuidar do ambiente.

Você acha que a Oficina deva continuar fazendo parte do Plano Político Pedagógico do Centro em 2012? Por qual motivo?

R - Sim, pelos pontos positvos citados acima e por ser uma oferta de atendimento pedagógico eficaz que produz resultados significativos e mudança de comportamento nos alunos. 